\title{
Políticas Públicas, trabalho e fronteiras ${ }^{233 *}$
}

\author{
Public policy, and working borders
}

\begin{abstract}
...A realidade das migrações, com as dimensões que assume na nossa época de globalização, precisa ser tratada e gerida de uma maneira nova, justa e eficaz, o que exige, acima de tudo, uma cooperação internacional e um espírito de profunda solidariedade e compaixão. É importante a colaboração em vários níveis, com a adoção unânime de instrumentos de regulamentação para proteger e promover a pessoa humana...Cidade do Vaticano, 05 de agosto de 2013.PAPA FRANCISCO I
\end{abstract}

Gina Vidal Marcílio Pompeu

Doutora em Direito pela Universidade Federal de Pernambuco (UFPE); Coordenadora e Professora do Programa de Pós-Graduação Stricto Sensu de Mestrado e Doutorado em Direito Constitucional da Universidade de Fortaleza (UNIFOR). E-mail: ginapompeu@unifor.br.

\section{Marina Andrade Cartaxo}

Doutoranda pelo Programa de Pós-Graduação Stricto Sensu em Direito Constitucional da Universidade de Fortaleza (UNIFOR); Professora auxiliar do Centro de Ciências Jurídicas da Universidade de Fortaleza (UNIFOR). E-mail: mcartaxo@ gmail.com

\section{Nardejane Martins Cardoso}

Mestranda pelo Programa de Pós-Graduação Stricto Sensu em Direito Constitucional da Universidade de Fortaleza (UNIFOR); Bolsista da Fundação Cearense de Apoio ao Desenvolvimento Científico e Tecnológico - FUNCAP. E-mail: nardejane_martins@hotmail.com

RECEBIDO EM: 17.06.2014

AProvado EM: 02.08.2014

233 * Trabalho desenvolvido por membros do Centro de Estudos Latino Americanos (CELA) e participantes do Grupo de Pesquisa "Relações Econômicas, Políticas e Jurídicas na América Latina" do Conselho Nacional de Desenvolvimento Científico e Tecnológico (CNPq). 


\section{Resumo}

O Brasil é detentor de vasto espaço territorial que confronta com outros países da América do Sul, porém, cumpre lembrar, que foi o único país colonizado por Portugal e uma vez independente adotou a forma de governo monárquica, enquanto que todos os vizinhos foram colonizados pela Espanha e, uma vez independentes, adotaram o regime republicano. Nesse contexto, fala-se que o Brasil vive de costas para a América Hispânica, e assim não exercita o princípio da alteridade. Nesse diapasão,se observam marcos regulatórios inerentes aos imigrantes e ou fronteiriços e, nesse viés, verifica-se a existência de solidariedade, tolerância e inclusão no que é pertinente a aculturação de valores distintos, bem como de garantia à efetivação dos direitos sociais, sobremaneira ao trabalho. São investigadas as ações do Executivo no que consistem ao incremento de políticas públicas imigratórias que reservem proteção e promoção do direito ao trabalho e ao exercício da cidadania;verifica-se a promulgação de legislação pertinente à matéria que revele proteção ao trabalhador migrante e à sua família.A metodologia adotada é histórica, bibliográfica, doutrinária, documental, legislativa, e jurisprudencial. Tem como resultados esperados a perspectiva de contribuir para a inserção do Brasil como signatário do Pacto das Nações Unidas e da defesa da promulgação de Legislação correspondente às carências brasileiras. Esse país de emigração e de imigração deve mostrar-se conectado com os fundamentos dos direitos humanos internacionais que conciliam crescimento econômico com desenvolvimento humano.

Palavras-chave: Fronteiras. Políticas públicas. Trabalhador imigrante. CresciMENTO ECONÔMico. DesEnVOLVIMENTO humano.

\section{Abstract}

Brazil holds a vast territorial space that confronts other countries in South America, however, it should be remember, that it was the only country colonized by Portugal, and once independent, it became a monarchical government, while all the neighbors were colonized by Spain and once independent time, adopted the republican regime. In this context, it is said that Brazil is backwards to the Hispanic America, and so do not exercise the principle of otherness. In this vein, regulatory frameworks relating to migrants and border are observed, and in this bias, the existence of solidarity, tolerance and inclusion are verified, in what is relevant to acculturation of distinct values and guarantee the fulfillment of social rights, greatly to work. The Executive Power actions are investigated, consisting in the increase of immigration policies that reserve protection and promotion of labor rights and citizenship; there 
is the enactment of legislation concerning this matter that protects the migrant worker and his family. The methodology adopted is historical, bibliographic, doctrinal, documentary, legislative, and jurisprudential. Has as expected results the prospect of contributing to the insertion of Brazil in the United Nations Convention as a signatory country and the defense of the promulgation of a legislation corresponding to the Brazilian needs. This country of emigration and immigration should be connected with the fundamentals of international human rights that combine economic growth with human development.

Keywords: Borders. Public Policy. Immigrant worker. Economic growth. Human DEVELOPMENT,

SuMÁRIO: Introdução. 1. Globalização, fluxos migratórios e desenvolvimento. 2. Trabalhadores migrantes e legislação no Brasil. 2.1. Retrospectiva constitucional e legal da imigração no Brasil. 2.2. O projeto de lei n. 5.655 de 20 de julho de 2009. 2.3. O anteprojeto de 2014. 2.4. A situação do fronteiriço. 2.5.Imigração irregular, as leis de anistia e refugiados. 2.5.1. Bolivianos e haitianos, irregulares e refugiados. 2.5.2 As leis de anistia. 2.6. A imigração regular no estado do Ceará. 3. Políticas públicas migratórias. 3.1. Políticas públicas imigratórias no Brasil: Direitos Humanos ou Desenvolvimento? Conclusão. Referências.

\section{INTRODUÇÃO}

O Brasil possui vasta extensão de fronteiras na América do Sul. No total são $15.179 \mathrm{~km}$ de fronteiras com 10 dos 12 países da América do Sul. Apenas o Chile e o Equador não fazem divisas com o Brasil. Nesse sentido, curioso lembrar que, a maior zona de fronteira com a França é aquela demarcada pelo Brasil e a Guiana Francesa, que perfaz655 km de fronteira, situada no estado do Amapá. O país tem593 kms de fronteira com Surinameentre os estados do Amapá (52 km) e Pará (541 km); com a Guiana, nota-se 1.606 km, sendo no estado do Pará (642 km) e Roraima (964 km);observa-se com a Venezuela, o total de 1.492, comfronteira nos estados de Roraima (954 km) e Amazonas (538 km); ainda com limites na Região Norte brasileira tem-se que a Colômbia perfaz $644 \mathrm{~km}$ de fronteira situada no território do estado do Amazonas,tem-se com oPeru, $2.995 \mathrm{~km}$ de fronteiras com o Amazonas $(1.565 \mathrm{~km})$ e Acre $(1.430 \mathrm{~km})$;revela-se com a Bolívia o total de $3.126 \mathrm{~km}$ de fronteiras, sendo no Acre $(618 \mathrm{~km})$, Rondônia $(1.342 \mathrm{~km})$, Mato Grosso $(780 \mathrm{~km})$ e Mato Grosso do Sul (386 km); já com o Paraguai, são1.339 km de fronteira, sendo no Mato Grosso do Sul (1.131 km) e Paraná (208 km).Na Região Sul, o Brasil tem 
com a Argentina, $1.263 \mathrm{~km}$ de fronteiras, sendo no Paraná (293 km), Santa Catarina $(246 \mathrm{~km})$ e Rio Grande do Sul (724 km); e por fim, com oUruguai possui $1.003 \mathrm{~km}$ de fronteira, totalmente com o Rio Grande do Sul.

Diante da constatação de que onze estados brasileiros fazem fronteira com 10 países na América do Sul, há de se acreditar que o Brasil possui políticas públicas de integração entre brasileiros e os demais sul-americanos no que é pertinente ao princípio da alteridade, do respeito mútuo e da garantia da efetivação de direitos sociais para os moradores das áreas fronteiriças.Nessa perspectiva revela-se essencial conhecer a intensidade do fluxo migratório entre esses países e a repercussão para o crescimento econômico e para o desenvolvimento humano dos Estados envolvidos.

Por meio desse artigo, tem-se o propósito de averiguar a realidade fática e legal que envolve esse assunto. Nota-se a prevalência de visão multifacetada sobre a questão das fronteiras.Nesse contexto, emigração e imigração, trabalho e políticas públicas perpassam por visões políticas, históricas, jurídicas e econômicas de diversos matizes.

Cumpre afirmar, que sob a ótica desse trabalho, pretende-se discutir as teorias de políticas migratórias a partir de uma perspectiva constitucional e humanista e, nesse diapasão adotam-se dois referenciais: i) o interesse de desenvolvimento do país; e ii) as garantias individuais da pessoa humana como sujeito de direitos universais.

Nota-se que a emigração acarreta o enfraquecimento dos elos de cidadania do Estado Nação. Sabe-se que a busca por trabalho e renda é a mola propulsora de grande parte dessa emigração, porém, na América Latina, se faz necessário analisar as questões de divergências políticas que provocaram as guerrilhas, insegurança e fuga das populações atingidas.

Com o escopo de manter o vínculo com o emigrante, entende-se que o Estado original deve pensar aquele fenômeno como passageiro, nesse viés, é uma opção facilitar a saída e quem sabe o futuro retorno do seu cidadão. Assim, estreitar os laços, acordos e relacionamento com o país receptor, capacitar o cidadão e qualificá-lo para a inserção no mercado de trabalho, bem como eliminar barreiras domésticas ao ingresso de remessas de capital, são ações que contribuirão para a sustentabilidade regional.

A visão do Estado Nação desenvolvido tem como foco principal executar políticas que garantam aos seus nacionais o gozo dos direitos fundamentais e sobremaneira o acesso ao emprego e à renda. Se o imigrante representar um fardo às dotações orçamentárias do Estado, ou ainda, se gerar insegurança e instabilidade social, o governo que recebe exercerá com rigoro controle de fronteiras e de imigração.As políticas de imigração têm se demonstrado extremamente relevantes para as relações internacionais, pois a decisão de um Estado de facilitar ou de restringir a imigração em seu território afeta outros Estados e a economia em geral. 


\section{GlobalizaÇão, FluXos migratórios e desenvolvimento}

O fenômeno da globalização, no século XXI, proporcionou a internacionalização social, econômica e cultural, como nunca antes vista, e também possibilitou maior fluxo de pessoas. Segundo as Atas da $67^{\mathrm{a}}$ e $68^{\mathrm{a}}$ Sessões da Assembleia Geral das Nações Unidas (ONU, 2012, online), mais pessoas viviam fora de seus países do que em qualquer outro momento da História. Nesse viés, o número global de migrantes internacionais teria aumentado de 155 milhões, em 1990 para 214 milhões em 2010,e em 2013 essa cifra alcançou 232 milhões de migrantes internacionais em todo o mundo. A reunião da ONU, entre 150 países diferentes, ocorreu em julho de 2013, e teve como cenário mundial a transição demográfica, o crescimento econômico e a globalização dos mercados de trabalho e a crise financeira. Nesse contexto analisou a situação dos imigrantes presos em situações ambientais e humanitáriasdesastrosas e apontou recomendações que deverão ser inseridas nas metas de pós-2015 (ONU, 2013, online).

As Nações Unidas afirmam que migração internacional, desenvolvimento e direitos humanos estão intrinsecamente conectados. Respeitar os direitos humanos e liberdades fundamentais de todos os migrantes é essencial para se colher os benefícios da migração internacional. E por isso, migrantes em situação irregular são particularmente vulneráveis à discriminação e abuso.

Vale ressaltar que desde o Compromisso de Montevidéu sobre Migrações e Desenvolvimento, assinado pelos Chefes de Estado e de Governo da Comunidade Ibero-Americana em 5 de novembro de 2006, ficou estabelecido que o tema da migração é realidade que guarda estreita relação com a falta de desenvolvimento, o desrespeito aos direitos humanos, ao desemprego, à pobreza, aos desastres naturais, à instabilidade na distribuição de riquezas e à falta de oportunidade para o desenvolvimento humano.

A Assembleia Geral da ONU, de julho de 2013, sobre Globalization and interdependence, International migration and development, incluiu entre as suas recomendações o dever de reforçar o diálogo, a cooperação ea coerência em todos os níveis, assim assevera:

Regional cooperation on migration has grown significantly in recent years. Regional economic communities have witnessed a renewed interest in implementingprovisions for the free movement of labour and started to focus on the developmentimpacts of migration. The European Union, for instance, has as one of its foundingprinciples the free movement of its citizens and has developed standards forportability of health care and pensions. The Southern Common Market(MERCOSUR) and the Caribbean Community (CARICOM) have also introducedmeasures to promote the free movement of their citizens(ONU, 2013). 
Cumpre lembrar, que no centro dessa conjuntura entre Estados, Mercados eglobalização estão as pessoas e a determinação internacional em defesa dos direitos humanos. Os sujeitos destinatários das declarações internacionaisbuscam trabalho, segurança e vida melhor para si e suas famílias, nesse sentido, o Secretário-Geral da sessão da ONU, em seu relatório aos Estados-Membros para o Diálogo de Alto Nível, na $68^{\mathrm{a}}$ Assembleia Geral, propôs agenda de oito pontos para a ação:

1. roteger os direitos humanos de todos os migrantes;

2. Reduzir os custos de migração laboral;

3. Eliminar a exploração de migrantes, incluindo tráfico de seres humanos;

4. Abordar a situação dos imigrantes retidos;

5. Melhorar a percepção pública dos migrantes;

6. Integrar a migração na agenda de desenvolvimento;

7. Fortalecer a base de evidências da migração e,

8. Intensificar parcerias de migração e cooperação.

Nenhuma sociedade pode considerar seu futuro sem ter em conta os efeitos da mobilidade humana. A $68^{\mathrm{a}}$ Assembleia Geral das Nações Unidas denunciou que poucos canais existem para a migração legal. Os direitos humanos dos migrantes, portanto, ficam comprometidos. Nesse contexto, observa-se que milhões viajam, vivem e trabalham fora da proteção legal. Como resultado, aqueles que exploram migrantes - contrabandistas, traficantes, recrutadores e empregadores corruptos e inescrupulosos - ganham mais poder.

Conclui-se que acomunidade internacional necessita construir um sistema adaptável de migração internacional que responda às carências do século XXI e que imprimam nas relações de trabalho mais fiscalização e apoio. Haja vista que, o acesso ao emprego e à renda, e assim à estabilidade e inclusão social são as metas de todos os seres humanos, inclusive dos migrantes e fronteiriços.

Verifica-se que a migração continua a aumentar em escopo, complexidade e impacto. Transição demográfica, crescimento econômico e a recente crise financeira reformulam a face da migração. No coração do fenômeno estão pessoas que buscam trabalho decente e vida melhor. Em todo o mundo milhões estão preparados para se mudar, viver e trabalhar em segurança e com dignidade por intermédio do acesso à educação sistemática e à capacitação para o trabalho. Noutro viés, outros estão obrigados a se mover devido à pobreza, violência e conflito, ou mudanças ambientais, e nessa vertente, enfrentam exploração, discriminação, preconceito, abuso e outras violações dos direitos humanos ao longo do caminho.

Consciente que a mobilidade humana é crescente no século XXI, Estados e instituições se ocupam dessa matéria, assim, vale ressaltar que a Igreja católica, com toda a sua capilaridade na América do Sul, preocupa-se com a fragilidade das rela- 
ções humanas e com as diferenças econômicas que excluem parcela da humanidade de usufruir da dignidade humana proveniente do acesso à saúde, trabalho e alimentação adequada. Nessa vertente,os fenômenos migratórios estão relacionados à busca por melhores condições de vida, que por vezes depara-se com a rejeição, a discriminação que podem ser transformadas em solidariedade, acolhimento e inclusão, assim o Papa Francisco I encaminha mensagem de otimismo aos migrantes e refugiados:

Queridos migrantes e refugiados! Não percais a esperança de que também a vós está reservado um futuro mais seguro; Que possais encontrar em vossos caminhos uma mão estendida; que vos seja permitido experimentar a solidariedade fraterna e o calor da amizade! Para todos vós e para aqueles que dedicam suas vidas e suas energias ao vosso lado eu prometo a minha oração e concedo de coração a minha Bênção Apostólica. (FRANCISCO I,Cidade do Vaticano, 05 de agosto de 2013).

\section{Trabalhadores imigrantes E legislaÇÃo no Brasil}

Falar de barreiras à imigração no Brasil soa estranho, diante da clara evidência de que os brasileiros nativos indígenas, de acordo com o último censo do IBGE de 2010, somam apenas 896.917 (0,47\% da população brasileira). Nesse diapasão, 99,53\% da população brasileira é formada por descendentes de imigrantes, sejam africanos, europeus ou asiáticos. Todos aqui chegaram como imigrantes construíram suas casas, famílias e comunidades. Falou-se no início da república brasileira em migração seletiva, ou seja, incentivo à migração europeia para substituir a mão de obra escrava e colaborar com o "embranquecimento da população".

Verifica-se que a formação do Estado brasileiro ocorreu por intermédio do processo de imigração. A partir do século XVI, com as grandes navegações, os europeus passaram a colonizar as terras, hoje, Americanas. No Brasil, durante este período, preponderou a entrada de portugueses e africanos, devido ao regime escravocrata e economia baseada na agricultura, especificamente na plantação de cana de açúcar. No contexto do século XIX, com a crise da indústria açucareira, passou-se a investir na produção do café. Em seguida, devido à abolição da escravatura em 13 de maio de 1888, houve a inserção de mão de obraeuropeia.Precipuamente, estrangeiros com nacionalidade portuguesa, italiana, hispânica, japonesa e alemã imigraram ao Brasil. Até meados da década de 1960, o Estado brasileiro era considerado um país de imigração.

De acordo com o relatório da OIM (International Organization for Migration)a imigração vem sendo regulada por legislações austeras, focadas na questão dasegurança nacional. Destarte, compreende-se a rigidez normativa pela situação política brasileira, à época, na qual se instalou o Regime Militar que perdurou por 21 anos. Durante aquele período foi promulgado o Estatuto do Estrangeiro, Lei n. 6815 
de 19 de agosto de 1980. Fundamentada nos princípios da Constituição de 24 de janeiro de 1967, o Estatuto tem o objetivo principalde proteger o Estado internamente.

Após o término do Regime Militar, com a perspectiva da redemocratização e mudança dos paradigmas constitucionais, durante a década de 1990, o governo brasileiro tentou alterar ostraços autoritários na regulação da situação das imigrações. Não obstante, não houve modificação da legislação infraconstitucional. Esta foi recepcionada pela Constituição brasileira de 1988, e encontra-se, ainda no ano de 2014, vigente no ordenamento jurídico.

A Constituição brasileira de 1988 promoveu a discussão sobre os aspectos inerentes à dignidade humana, ao mínimo existencial e à reserva do possível, bem como da necessária transformação de normas programáticas em normas de eficácia plena. Revela-se a adoção dos conceitos de Konrad Hesse e da opção pela força normativa da constituição. Sob essa ótica, a legislação brasileira superou a legislação alemã, que não prevê o direito subjetivo aos direitos sociais, bem como à legislação chilena, que prevê, mas não assegura meios processuais. O Brasil prevê, e garante meios processuais de execução. Observa-se que vigora, hodiernamente, a posição concretista do Judiciário.

Nesse contexto, enfrenta o dilema da judicialização da política e do ativismo judicial, bem como, enfrenta o debate da contradição entre as funções típicas dos "Poderes do Estado,"e o princípio da separação de poderes. Revela-se a dificuldade do Executivo promover a efetivação de políticas públicas capazes de cumprir as promessas constitucionais.

As ordens, social e econômica, previstas no texto constitucional, apresentam como instrumentos de efetivação o planejamento orçamentário, por meio da previsão legal do PPA- Plano Plurianual, da LDO - Lei de diretrizes orçamentárias, e da LOA- Lei orçamentária anual, porém essas leis orçamentárias são autorizativas e não impositivas. Nessa perspectiva, o rol dos artigos destinados aos direitos humanos e sociais, e toda ordem social padecem sob os fatores reais do poder, e revigoram as afirmações de Ferdinand Lassalle (1974).

Assevera-se que o constitucionalismo brasileiro dedicou os artigos $5^{\circ}, 6^{\circ}$ e $7^{\circ}$ à positivação dos direitos humanos, declarando-os direitos fundamentais de eficácia imediata. Tem-se no art. $5^{\circ}$, destinado à proteção da vida, liberdade, igualdade, segurança e propriedade, setenta e oito incisos, quatro parágrafos. $\mathrm{O}$ art. $6^{\circ}$ é dedicado a afirmar o direito subjetivo à educação, à saúde, à alimentação, ao trabalho, à moradia, ao lazer, à segurança, à previdência social, à proteção à maternidade e à infância, à assistência aos desamparados. Por fim o art. $7^{\circ}$ dispõe sobre os direitos trabalhistas em XXXIV incisos e um parágrafo único.No mesmo contexto. Nesse viés, de acordo com a perspectiva de Patrícia Bertolin e Alessandra Tupiassú (2011, online) o direito social ao trabalho também é direito fundamental, e, portanto, estende-se aos imigrantes.

Importa, nesse sentido, recordar que o artigo $4^{\circ}$ da Constituição brasileira 
de 1988 ao tratar dos princípios das relações internacionais, afirma que a República Federativa do Brasil buscará a integração econômica, política, social e cultural dos povos da América Latina, e nesse diapasão, visa à formação de uma comunidade latino-americana de nações.

Cumpre esclarecer que, no que se refere à diferenciação entre trabalhadores imigrantes e brasileiros, que deverão ser observados tanto a Constituição brasileira de 1988, como no âmbito supraconstitucional, a Convenção n. 97 de 22 de janeiro de 1952 da Organização Internacional do Trabalho, cujo tema principal é o trabalho de imigrantes. Segundo o artigo $6^{\circ}$ da Convenção, os membros que a ratificaram devem conferir tratamento paritário aos imigrantes ${ }^{234}$.

Neste diapasão, constata-se que não deve existir diferença entre trabalhadores brasileiros e trabalhadores estrangeiros. Vê-se que o Projeto de Lei n. 5.655/09, ao dispor sobre a proteção dos trabalhadores nacionais como um dos objetivos precípuos da norma, está dissociado da perspectiva da imigração pelos Direitos humanos, proposta pela convenção supramencionada.

No mesmo sentido da convenção anterior, embora não esteja ratificada pelo Brasil, a Convenção n. 143 da OIT, que trata sobre as imigrações feitas em condições abusivas e necessidade da promoção da igualdade dos migrantes, no artigo $9^{\circ}$, informa que ainda que o imigrante esteja irregular, ele deve gozar dos mesmos direitos que trabalhador brasileiro ${ }^{235}$. Ressalta-se que mesmo não ratificada a Convenção n. 143, ela é utilizada por parâmetro para decisões na seara trabalhista.

Apesar da existência de acordos internacionais, persistem casos de utilização de mão de obra, informal, de imigrantes bolivianos que adentram o Brasil de forma irregular. Destarte, importante compreender que no Direito Trabalhista, não importa a regularidade do imigrante, mas sim, se ele trabalhou, por isso, os bolivianos, mesmo irregulares, têm direito às verbas e garantias trabalhistas. A situação de irregularidade não lhe obsta o gozo dos direitos na seara trabalhista.

Cumpre lembrar que a Consolidação das Leis Trabalhistas (Decreto-lei n. 5.452 , de $1^{\circ}$ de maio de 1943 ), por ter sido promulgada no contexto da década de 1940, no período do governo de Getúlio Vargas, estabelece prioridade ao trabalhador nacional. Segundo artigo 352 da CLT deve existir uma porção mínima de trabalha-

\footnotetext{
234 "Art. 6 - 1. Todo Membro para o qual se ache em vigor a presente convenção se obriga a aplicar aos imigrantes que se encontrem legalmente em seu território, sem discriminação de nacionalidade, raça, religião ou sexo, um tratamento que não seja inferior ao aplicado a seus próprios nacionais com relação aos seguintes assuntos [...]".

235 “ARTIGO 9. 1 - Sem prejuízo das medidas destinadas a controlar os movimentos migratórios com fins de emprego garantindo que os trabalhadores migrantes entram no território nacional e aí são empregados em conformidade com a legislação aplicável, o trabalhador migrante, nos casos em que a legislação não tenha sido respeitada e nos quais a sua situação não possa ser regularizada, deverá beneficiar pessoalmente, assim como a sua família, de tratamento igual no que diz respeito aos direitos decorrentes de empregos anteriores em relação à remuneração, à segurança social e a outras vantagens".
} 
dores nacionais em concessionárias de serviço público, por exemplo, e o artigo 353 afirma que o estrangeiro somente se equipara ao trabalhador nacional, quando residindo há dez anos no Brasil, casado ou com filho brasileiros, ou com nacionalidade portuguesa.

É possível observar ao longo da legislação brasileira a preferência no Estado Brasileiro pela atração de mão-de-obra qualificada, ou seja, pessoas com perfil educacional elevado, que possuam nível superior completo. Essa análise é tratada por Aldacy Coutinho (2007, p. 373), quando explica que os avanços tecnológicos, a partir da década de 1990, e necessidade de lucro pelas empresas-empregadoras fazem com que se exija do trabalhador qualificação especializada. $\mathrm{O}$ acesso à educação torna-se fulcral para a concessão de vistos no Brasil.

Por outro lado, Antonio Rodrigues Freitas Jr. (2014) adverte sobre a fragilização do Direito do trabalho, haja vista os fatores como a diminuição da força sindical, a crise do Estado-providência, associada à crise econômica de 2008. No mesmo sentido, Pedro Baltar (2014) alerta para a necessidade de política de geração de emprego por parte do Estado que proponha o aumento do número de vagas de trabalho e seu preenchimento com contratos formais.

Na mesma vertente de pensamento, Luiz Carlos Gama e Ana Flávia Machado (2014) concluem que as migrações causam efeitos econômicos, por intermédio de análise censitária do período de 2000 a 2010 no Estado brasileiro. Os autores abordam a temática no sentido de que as migrações causam impactos nas regiões de origem e de destino do migrante. Embora tratem das migrações internas, a dinâmica apresentada assemelha-se às migrações internacionais, principalmente pelas motivações dos migrantes: políticas, religiosas ou climáticas ou econômicas, como o caso dos que buscam melhores condições de emprego e renda.

Nesse sentido, verifica-se que o imigrante regular, que consegue visto de trabalho junto ao Ministério do Trabalho e Emprego (MTE) encontra-se protegido pela legislação nacional, inclusive, devido à ratificação da Convenção 97 da Organização Internacional do Trabalho (OIT), que visa proteger o trabalhador migrante regular. Já o Conselho Nacional de Imigração (CNIg), órgão vinculado ao MTE, é responsável pela concessão dos vistos aos imigrantes com finalidade laboral, e assim, o trabalhador imigrante regular está protegido e, nos mesmos termos, contribuí para o desenvolvimento local, por meio do consumo e circulação de renda.

Porém, quando o imigrante é irregular e passa a trabalhar na informalidade, torna-se vulnerável, já que os direitos laborais não são respeitados. Apesar do Estado brasileiro não ter ratificado a Convenção 143 da OIT, que estabelece o reconhecimento dos direitos trabalhistas inclusive aos imigrantes irregulares, os tribunais nacionais reconhecem tais direitos. Como exemplo, tem-se o seguinte Recurso Ordinário n. 1553620115020 do Tribunal Regional da $2^{\mathrm{a}}$ Região, datado de 16 de maio de 2013, que apesar da vedação ao trabalho do imigrante irregular pela CLT e pelo Estatuto do Estrangeiro de 1980, o tribunal compreendeu que os direitos trabalhistas 
devem ser reconhecidos.

A decisão fundamentou-se nos artigos $1^{\circ}$, inciso III, $3^{\circ}$, inciso IV, $6^{\circ}$ e $7^{\circ}$ da Constituição Federal de 1988, bem como na Declaração Universal dos Direitos Humanos de 1948, e no Pacto de San José da Costa Rica de 1969. O reconhecimento do vínculo empregatício não ultrapassa os direitos trabalhistas, haja vista que o tribunal, não reconheceu os direitos previdenciários. Observa-se que a decisão não altera a irregularidade do imigrante.

Neste viés, conforme explicitado na decisão do tribunal, acima informada, o não reconhecimento dos direitos trabalhistas e respectivos encargos do empregador, pode funcionar como incentivo à contratação de mão de obra de imigrantes irregulares, haja vista a baixa onerosidade e impossibilidade condenação judicial. Destarte, observa-se a reflexão de Danilo Zolo (2014, p. 41), no que se refere aos fluxos imigratórios de países em desenvolvimento para países já desenvolvidos, no sentido de que a economia e as migrações internacionais e a proteção dos trabalhadores estão relacionadas.

[...] Il problema delle 'conseguenze umane' dela precarietà del lavoro e del reddito individuale - in termini di debole professionalità, incapacità di progettare la propria vita, disgregazione sociale - è una 'esternalità' (outsourcing) che sarà semmai il sistema politico a dover impostare e risolvere. Ma, ecco un punto delicatissimo, la crescente 'flessibilità' del lavoro sta portando, ache nei paesi europei di Welfare State, a un indebolimento dell'intero apparato delle tutele sociali garantite sinora ai lavoratori e alle loro famiglie: pensione, liquidazione, malattie, gravidanza, e così via [...].

Nesse diapasão, nota-se que a International Organization for Migration (IOM, 2012), em relatório de 2012, propõe o estudo e análise dos fluxos migratórios com foco nas questões laborais, de integração entre os países e cooperação, diante das saídas dos indivíduos dos seus Estados de origem, e relaciona desenvolvimento com migração. O relatório foi elaborado pelo Labor Migration and Human Development Division (LHD), este órgão observa as questões trabalhistas nos níveis locais, regionais e globais, e conclui que as migrações laborais são positivas de um modo geral para o desenvolvimento dos países. Contudo, observa-se a necessidade de políticas institucionais de proteção aos trabalhadores imigrantes, haja vista sua vulnerabilidade.

The Division is the Organization's focal point for guidance and technical support on labour migration, including facilitating the recruitment of temporary foreign workers and addressing related issues. LHD provides guidance and technical advice within IOM and to governments and partners on the regulation of labour migration, with the objective of promoting 
options for legal and safe migration for migrant workers, thus reducing their vulnerability. The work of LHD strengthens government efforts to protect migrants by enhancing the capacities of governments to manage labour migration flows and reduce irregular migration. LHD also facilitates bilateral discussions on labour recruitment and may be actively involved in the recruitment and placement of workers, subject to appropriate legal frameworks. Another important role of LHD is to monitor activities and developments in the area of labour migration and contribute to the organizational knowledge base by collecting lessons learned, identifying best practices related to labour migration and keeping abreast of trends. (IOM, 2012, p.11).

Segundo o relatório anual da IOM (2012) as razões para as migrações variam entre disparidades sociais e econômicas, fatores demográficos e pressões ambientais. Segundo, explica-se no relatório, apesar das crises econômicas, como a de 2008, a migração de trabalhadores, bem como os programas de desenvolvimento humano voltados aos fluxos migratórios permanecem como políticas públicas.

Em outro relatório da IOM, de setembro de 2013, foi analisada no Brasil a questão dos Direitos Humanos na política migratória do país. No relatório compreende-se que políticas de cunho migratório são àquelas que têm intenção direta de influenciar as dimensões fulcrais do processo migratório. Essas dimensões relacionam-se com a origem do migrante, o volume de migrantes, e, por fim, a composição dos fluxos migratórios quanto ao perfil social, econômico, demográfico ou cultural. Segundo relatório as políticas devem conciliar os interesses dos Estados envolvidos, da população migrante, dos setores econômicos e das comunidades dentro dos Estados nacionais.

Sob outra perspectiva, observa-se que o Estatuto do Estrangeiro foi recepcionado pela Constituição de 1988 e permanece no ordenamento como responsável por regular as questões atinentes à entrada e saída de pessoas, ou seja, ao fluxo de pessoas no território nacional. Contudo, revela-se que essa legislação tornou-se limitada, haja vista, não comportar todas as hipóteses de migração, e não prever políticas públicas adequadas às necessidades hodiernas, precipuamente à conciliação entre direitos humanos, desenvolvimento, capacitação e trabalho.

\subsection{O Estatuto do Estrangeiro de 1980}

No regime da Constituição de 1967 (e Emenda Constitucional n. 1 de 1969) vigeu por 12 anos o Decreto-lei no 941, de 13 de outubro de 1969, o "Estatuto do Estrangeiro". Ele englobava diversas matérias atinentes à entrada e à vida do estrangeiro no Brasil. Este diploma foi substituído pela Lei no 6.815 , de 19 de agosto de 1980, que rege os institutos da admissão e entrada do estrangeiro no território 
nacional, bem como, os vários tipos de vistos e suas modificações, a prorrogação do prazo de estada, a condição do asilado, o registro do estrangeiro, saída e retorno ao território nacional, documentação para viagem, a deportação, a expulsão, a extradição, os direitos e deveres do estrangeiro, a naturalização. Salienta-se, nesse diploma, a criação do Conselho Nacional de Imigração. No entanto, esta lei foi alterada em diversos dispositivos pela Lei. 6.924 de 29 de junho de 1981.

A filosofia desta legislação inspira-se no atendimento à segurança nacional, à organização institucional e nos interesses políticos, socioeconômicos e culturais do Brasil, inclusive na defesa do trabalhador. Proíbe, no artigo 37, a legalização do clandestino e do irregular, bem como a transformação em permanente dos vistos de trânsito, de turista, de cortesia e temporário, excetuados neste tipo os casos do cientista, professor, técnico ou profissional e de ministros de confissão religiosa.

A Constituição Federal de 05 de outubro de 1988 declara a dignidade humana como fundamento da República Federativa do Brasil. Nessa vertente de pensamento, foia primeira Constituição brasileira que tratou o estrangeiro, residente no Brasil, de forma isonômica, o que pode ser observado no caput do artigo $5^{\circ}$, que consagra os direitos fundamentais e ainda diante da leitura dos princípios que norteiam as relações internacionais do Brasil e garantem a prevalência dos direitos humanos e autodeterminação dos povos e a cooperação para o progresso da humanidade no art. $4^{\circ}$. Portanto, essa ordem constitucional exige do Estado aimplementação de políticas públicas que garantam a dignidade do estrangeiro bem como a integração deste no meio social e cultural brasileiro, sem nenhum tipo de descriminação ou paternalismo estatal. Essa tendência, de defesa dos direitos humanos e sociais que tem como destinatários, brasileiros e estrangeiros migrantes, tende a provocar mudanças na legislação infraconstitucional.

A Lei n. 6.815/1980, conforme já explanado, foi elaborada no período em que estava vigente a Constituição brasileira de 1967, durante o Regime Militar. Por isso, devido ao contexto histórico em que foi produzida, a legislação caracteriza-se pelo nacionalismo, desenvolvimentismo e proteção ao trabalhador brasileiro. $\mathrm{O}$ artigo $1^{\circ}$ do Estatuto do Estrangeiro afirma que nos períodos pacíficos, sem ausência de conflitos belicosos ou armados, o estrangeiro, que cumprir os requisitos legais, pode entrar, sair ou permanecer no Estado brasileiro. Resguarda-se, sobretudo, o interesse nacional. $\mathrm{O}$ artigo $2^{\circ}$, da mesma forma, ressalta que a aplicação da lei atenderá prioritariamente à segurança nacional, à organização institucional, aos interesses políticos, sociais e culturais brasileiros, e por fim, à defesa do trabalhador nacional. Já o artigo $3^{\circ}$, em seguida, condiciona a concessão dos vistos aos interesses brasileiros.

Vê-se, portanto, que o viés imanente do Estatuto do Estrangeiro de 1980, que permanece vigente na ordem constitucional de 1988, é a proteção dos interesses do Brasil. Sua vertente nacionalista não se preocupa, precipuamente com os Direitos Humanos dos imigrantes, mas com os direitos dos brasileiros, com a proteção do 
território nacional, e, nesse diapasão, as políticas imigratórias devem estar voltadas ao desenvolvimento local.

Por outro lado, o Estatuto do Estrangeiro de 1980, em seu artigo 128, estabeleceu a criação do Conselho Nacional de Imigração (CNIg) órgão do Ministério do Trabalho e Emprego vinculado ao Poder Executivo, responsável por orientar, coordenar, fiscalizar as atividades de imigração. Sua organização e funcionamento são definidos pelos Decretos n. 840, de 22 de junho de 1993, e n. 3.574, de 23 de agosto de 2000 .

De acordo com o Decreto n. 840/93, art. $2^{\circ}$, o CNIg é composto por diversos membros dos ministérios do Poder Executivo, representantes dos trabalhadores, empregadores e comunidade científica, indicados por suas categorias profissionais. $\mathrm{O}$ artigo $3^{\circ}$ do presente decreto esclarece que não há remuneração pelo exercício do cargo, em que pese à relevância do serviço público, haja vista ser o CNIg responsável pelas políticas imigratórias, por meio de resoluções.

Ao retratar as políticas imigratórias, André Siciliano (2013, p. 28) disserta sobre o Estatuto do Estrangeiro de 1980 e explica que um dos fatores principais para a política de segurança nacional disposta na legislação era a falta de concordância dos militares com as interferências de estrangeiros no Brasil. O autor explica ainda, que cabe ao CNIg também verificar a alocação e trabalhadores imigrantes no mercado brasileiro, e por este motivo o conselho está vinculado ao TEM (Ministério do Trabalho e Emprego), demonstra o viés de proteção do mercado de trabalho nacional.

Verifica-se a partir de 2009, a existência de duasproposições normativas que visam substituir o Estatuto do Estrangeiro. Tramita no Congresso Nacional o projeto de Lei n. 5.655 de 20 de julho de 2009 que contextualiza a necessidade de políticas migratórias detentoras do escopo de conciliar o desenvolvimento local com os direitos humanos. Já o anteprojeto de 2014 prioriza a criação da Lei de Migrações voltada à efetivação dos Direitos Humanos.

No que concernem às políticas públicas voltadas às migrações em busca de emprego, dados do Ministério do Trabalho e Emprego, entre os períodos de 2011 a março de 2014 (BRASIL, MTE, 2014, online), demonstram tendência da política de migrações brasileira para concessão de vistos de trabalhos aos estrangeiros com alto nível de capacitação laboral. Em relação ao tipo de visto, 9.366 foram permanentes e 199.847 temporários. Entre os 9.366 vistos de prazo permanente, 3.388 foram para investidor pessoa física, 4.490 para administradores, diretores, gerentes e executivos com poder de gestão, e 1.230 para outros tipos de trabalho, como professores, pesquisadores, representantes de sociedades estrangeiras e de conglomerados econômicos.

Segundo artigo apresentado por Marcus Spollee Ana Cristina Fabres (2014, online), que relata estudo sobre trabalhadores estrangeiros especializados em construção naval, realizado na cidade de Rio Grande (RS), observa-se que estes 
imigrantes são contratados por empresas brasileiras, por período de três a seis meses, uma vez que os trâmites para visto de permanência superior a noventa dias são complexos. Nesse viés, as empresas optam pelo visto mais simples, ainda que seja necessária a permanência de trabalhadores especializados por períodos mais longos.

\subsection{O Projeto de Lei n. 5.655 de 20 de JUlho de 2009}

O Projeto de Lei n. 5.655 de 20 de julho de 2009 é de iniciativa do Governo Federal e encaminhado ao Congresso Nacional. A partir da justificativa do projeto, constata-se que o objetivo da legislação é fomentar o desenvolvimento de políticas públicas na seara da migração voltadas ao desenvolvimento econômico, social e cultural do Brasil.

No começo do século XXI, muitos brasileiros que viviam no exterior retornaram ao Brasil em virtude da crise econômica de 2008, bem como muitos estrangeiros adentraram no país, por isso o Poder Executivo preocupou-se em debater a questão e propor a elaboração de legislação que abordasse as questões migratórias. Em 2009 o PL n. 5655/09 foi fundamentado na globalização e na carência de políticas públicas eficientes em tal seara. O projeto de lei em comento respalda-se na busca pela efetivação dos Direitos Humanos, fortalecimento das relações internacionais, e interesses nacionais, sociais, culturais e econômicos.

Diante da leitura do art. $1^{\circ}$ do PL n. 5.655/09 observa-se que tem como foco dispor sobre os seguintes temas: permanência, saída e entrada de estrangeiros; instituto da naturalização; transformação do Conselho Nacional de Imigração (CNIg) em Conselho Nacional de Migração (CNMg); e outras medidas compulsórias, infrações e demais providências. O parágrafo único alberga a definição de estrangeiro, assim, será considerada estrangeira a pessoa que não possuir a nacionalidade brasileira ${ }^{236}$.

Os principais objetivos da legislação proposta são: criação de política nacional de migração pautada nos Direitos Humanos, nos interesses nacionais socioeconômicos e culturais, na preservação e melhoramento das instituições democráticas, e, por fim, no fortalecimento das relações internacionais. Nota-se a relação do projeto com o artigo $4^{\circ}$ da Constituição Federal de $1988^{237}$. A norma constitucional

236 "Art. 1'. Esta Lei dispõe sobre o ingresso e permanência de estrangeiros no território nacional, a aquisição e efeitos da nacionalidade brasileira por naturalização, a repatriação, deportação, expulsão e extradição passiva e ativa, transforma o Conselho Nacional de Imigração em Conselho Nacional de Migração, e define infrações e suas sanções. Parágrafo único. Considera-se estrangeiro todo aquele que não possui a nacionalidade brasileira originária ou adquirida”. (Grifou-se)

237 “Art. $4^{\circ}$ A República Federativa do Brasil rege-se nas suas relações internacionais pelos seguintes princípios: I - independência nacional; II - prevalência dos direitos humanos; III - autodeterminação dos povos; IV - não-intervenção; V - igualdade entre os Estados; VI - defesa da paz; VII - solução pacífica dos conflitos; VIII - repúdio ao terrorismo e ao racismo; IX - cooperação entre os povos para o progresso da humanidade; X - concessão de asilo político. 
expõe os princípios pelos quais as relações internacionais devem ser guiadas. Entre tais princípios encontram-se a prevalência dos Direitos Humanos e a cooperação entre os povos para o desenvolvimento da humanidade.

Ressalta-se que a partir do texto do artigo $4^{\circ}$ relativo ao PL n. $5.655^{238}$ depreende-se que o escopo precípuo da política imigratória é a admissão da entrada no Brasil de mão de obra qualificada. Além da qualificação, a formação do imigrante deve se adequar aos setores da economia brasileira. $\mathrm{O}$ dispositivo ressalta que a finalidade da imigração é contribuir para o desenvolvimento social, econômico, cultural, científico e tecnológico, bem como a capitação de recursos e geração de emprego e renda. O prospecto de norma, também, evidencia a proteção do trabalhador nacional.

Decorrente do artigo supramencionado tem-se o artigo 21 que dispõe acerca do visto temporário, bem como o artigo 34, incisos III, V, VI ${ }^{239}$ que trata sobre visto permanente. Nestas normas nota-se que a política imigratória está voltada ao desenvolvimento interno. Estes imigrantes adentram no território brasileiro com a justificativa de contribuição paracrescimento do país, seja por meio de investimentos, negócios, ensino, pesquisa, ou cultura. Desta forma, constata-se que o projeto em análise visa o desenvolvimento nacional em conciliação com os direitos humanos dos imigrantes. O Projeto de Lei, em outubro de 2014, ainda aguarda parecer da Deputada relatora daComissão de Relações Exteriores e de Defesa Nacional (CREDN) da Câmara dos Deputados.

\subsection{O AnTEProjeto de 2014}

Em 2013 o Ministério da Justiça, por intermédio da portaria n. 2.162, criou comissão responsável pela elaboração de anteprojeto de legislação com o escopo de ser a "Lei de migrações". Em 24 de abril de 2014 foi publicada a primeira versão

\footnotetext{
Parágrafo único. A República Federativa do Brasil buscará a integração econômica, política, social e cultural dos povos da América Latina, visando à formação de uma comunidade latino-americana de nações".

238 “Art. $\mathbf{4}^{\mathbf{}}$. A política imigratória objetivará, primordialmente, a admissão de mão-de-obra especializada adequada aos vários setores da economia nacional, ao desenvolvimento econômico, social, cultural, científico e tecnológico do Brasil, à captação de recursos e geração de emprego e renda, observada a proteção ao trabalhador nacional". (Grifou-se) 239 “Art. 34. O visto permanente poderá ser concedido ao estrangeiro que pretenda fixar-se definitivamente no Brasil, satisfeita uma das seguintes condições: [...]III - tiver notório conhecimento em sua área de atuação profissional e puder prestar serviços relevantes ao Brasil; [...] V - realizar investimento produtivo que contemple empregos diretos em número satisfatório, considerada a localidade do empreendimento no Brasil, e promova, de maneira direta ou indireta, o desenvolvimento econômico, social ou tecnológico do local onde for instalado; ou VI - tiver residido no Brasil como permanente e perdido essa condição em razão de ausência do País justificada por estudos de graduação ou pós-graduação, treinamento profissional, atividade de pesquisa ou atividade profissional a serviço do Governo brasileiro".
} 
do anteprojeto, que visa instituir a Lei de Migrações e criar a Autoridade Nacional Migratória (ANM).

No Anteprojeto de 2014 verifica-se maior importância às questões que envolvem Direitos Humanos, que corresponde à ética internacional de preservação e tratamento igualitário aos migrantes. No que se refere à dimensão do desenvolvimento interno e integração o anteprojeto dispõe no artigo $3^{\circ}$, inciso XVI, que a política migratória brasileira rege-se pela integração e desenvolvimento das regiões de fronteira. Fator que deve também ser relevante aos projetos que visam instituir legislações sobre o deslocamento de pessoas.

No artigo $1^{\circ}$ o anteprojeto revela o objetivo da futura legislação que é a proteção dos migrantes, enquanto gênero. Os parágrafos do artigo definem os tipos de migrantes. Imigrante como todo estrangeiro que transite, trabalhe ou resida no Brasil de forma permanente ou transitória $(\S 1)$. Nos $\S \S 2^{\circ}$ a $4^{\circ}$, o dispositivo conceitua imigrantes transitórios, temporários e permanentes. $\mathrm{O} \S 6^{\circ}$ define o emigrante como aquele que deixa o território nacional.

Verifica-se que o $\$ 5^{\circ}$ do artigo $1^{\circ}$ define o fronteiriço como a pessoa que reside em Município de fronteira. Nesse sentido, é interessante notar que o Estatuto do Estrangeiro e o PL n. 5.655/2009 albergam dispositivos que tratam do fronteiriço. O Estatuto do Estrangeiro em seu artigo 21 dá a mesma definição de fronteiriço, e disserta sobre a possibilidade do mesmo trabalhar e estudar no município brasileiro.

No mesmo sentido, o art. 73 do Projeto de Lei n. 5.655/2009 afirma que o nacional do país limítrofe pode trabalhar ou estudar em município do Brasil, desde que se habilite e passe a portar documentação específica. Tanto no projeto como a legislação em vigência, o fronteiriço não tem a liberdade de adentrar outras partes do território nacional, sem autorização.

Por sua vez, o anteprojeto em comento, em seu artigo $6^{\circ}$, é silente no que se refere à situação de mobilidade do fronteiriço, por não estar delimitado pela legislação se tal migrante pode ou não circular em outras partes do Brasil, que não o domicílio em que trabalha, estuda ou pratica alguma atividade autorizada.

Outro ponto vago do anteprojeto, que demonstra a empatia pelas nuances dos Direitos Humanos, é a questão de livre entrada e circulação dos povos indígenas, prevista no $\S 7^{\circ}$ do artigo $1^{\circ}$. O dispositivo reconhece os direitos dos povos indígenas originários, e lhes concede livre mobilidade, porém, não explica mais detalhes, e sequer preocupa-se com a diferenciação, haja vista que, passam a existir dois tipos de imigrantes na América Latina. Quebra-se a igualdade sem um motivo coerente para tanto.

Em seguida, observa-se que como o Projeto de Lei n. 5.655/09, o Anteprojeto de 2014 também prevê a criação de novo órgão responsável pela política imigratória. A denominação, segundo o anteprojeto, é Autoridade Nacional Migratória, órgão vinculado ao Governo Federal, segundo artigo 72 do Anteprojeto, será responsável pela fiscalização, concessão de vistos, participará em processos de na- 
turalização, expulsão, extradição etc. Segundo o artigo 91 do anteprojeto a ANM terá natureza de autarquia e atuará como autoridade administrativa independente. $\mathrm{O}$ artigo 95 dispõe órgãos que fazem parte da ANM e entre eles está o Conselho Nacional sobre Migrações (CMig).

Destarte, pondera-se que tanto o projeto de lei como o anteprojeto, em comento, devem ser estudados, haja vista a necessidade de leis adequadas às situações que envolvem as migrações. Por conseguinte, torna-se importante observar como se dão as mudanças de paradigmas normativos no que se referem às situações que envolvem às políticas imigratórias.Atenção especial merece ser deferida para o incremento de políticas públicas adequadas às carências dos fronteiriços, imigrantes de países limítrofes, refugiados e imigrantes em situação irregular.

\subsection{A SituaÇão do Fronteiriço}

O Estatuto do Estrangeiro (Lei n. 6.815 de 19 de agosto de 1980) define no artigo 21 o fronteiriço como aquele natural de país limítrofe. Nesse sentido, importa ressaltar que devido à extensão territorial, o Brasil faz fronteira com a maior parte dos países latino-americanos, excetuando-se apenas Chile e Equador.

Os parágrafos do artigo 21 do Estatuto do Estrangeiro regulam a situação do fronteiriço que trabalha ou estuda no município limítrofe. A estes estrangeiros é concedida uma identificação especial, porém, ela não significa que eles possuam direito de residir ou de adentrar o território brasileiro livremente. O artigo 99 da Lei n. 6.815/80 dispõe sobre outras restrições, relacionadas ao estabelecimento de empresas no Brasil por imigrantes de fronteira.

Segundo André Siciliano (2013, p. 37) nada obsta que o residente em município fronteiriço exerça trabalho remunerado, com direito à Carteira de Trabalho e Previdência Social. Contudo, ele não pode circular livremente, haja vista que fica restrito à cidade onde estuda ou trabalha. Explica o autor, também, que é necessária a apresentação do documento especial, que permite a entrada do estrangeiro no domić́lio de fronteira.

O Projeto de Lei n. 5.655 de 20 de julho de 2009, no mesmo sentido que a legislação vigente, acima comentada, refreia o acesso aos estrangeiros limítrofes, porém, de acordo com o artigo 73 do projeto, qualquer fronteiriço pode requerer o documento especial. O Anteprojeto de 2014, também possui dispositivos relativos aos fronteiriços. O capítulo III do anteprojeto de legislação é dedicado ao caso de estrangeiros de países limítrofes ao Brasil. Diferentemente, da atual lei e do projeto de lei, já abordados, o anteprojeto não impõe restrição ao estabelecimento ou exercício de empresas. Contudo, nas demais matérias,o Anteprojeto de 2014 repete o Estatuto do Estrangeiro, e assevera que em caso de infrações o imigrante perde a condição de fronteiriço.

Percebe-se que, mesmo com as novas formatações, o Estatuto do Estran- 
geiro vigente, e o Projeto de Lei n. 5.655/09 revelam a intenção de proteção do Estado brasileiro. Já no Anteprojeto de 2014, os elaboradores não se preocuparam em restringir a locomoção do fronteiriço apenas ao município onde reside, trabalha ou estuda. Em que pese à necessidade de integração entre os países da América Latina (intencionalidade constitucional prevista no artigo $4^{\circ}$ da Constituição Brasileira de 1988), deve-se observar com acuidade a situação do fronteiriço.

No que se refere à imigração na América Latina, Rossana Reis (2011, p. 64) ressalta a necessidade da integração regional entre o Brasil e os países fronteiriços, na medida em que se cumpra o disposto na Constituição Federal de 1988. Segundo a autora, a questão da migração regional, não pode ficar em segundo plano, deve ser ponto fundamental na política imigratória adotada pelo Brasil. Para tanto, compreende-se a necessidade de conhecer a situação de outros tipos de imigrantes, em caso, dos imigrantes irregulares e dos refugiados, que se diferenciam entre si, assim como dos fronteiriços.

\subsection{IMIGRAÇÃo IRREGULAR, AS LEIS DE ANISTIA E REFUGIADOS}

Carvalho e Junqueira (2013) identificam a situação, hodierna, de vulnerabilidade dos imigrantes, e sua necessidade de ser empregado no país de destino. Os autores explicam que diante da desigualdade entre os países, crise de desenvolvimento humano, insuficiência de empregos e qualificação, as relações de trabalho são o foco tanto dos imigrantes quanto dos nacionais.

Destarte, Carvalho e Junqueira (2013, p. 163) dissertam que o estrangeiro que se encontra legalmente residindo no país, consegue aproximar-se, um pouco mais, dos nacionais, por meio do status de regularidade. Em contrapartida, a falta de regularidade, situação marginal, acentua as diferenças, e por fim, justifica o tratamento do estrangeiro como "[...] forasteiro, bárbaro ou mesmo usurpador". Ainda assim, na perspectiva dos autores, independente da situação, o imigrante é visto como diferente. Os autores citados explanam que a problemática que envolve a imigração não se dá apenas na entrada regular de estrangeiro, mas também, e precipuamente, por esta percepção de que os imigrantes irregulares são destinados à clandestinidade e a servir como mão-de-obra barata.

\subsubsection{Bolivianos e Haitianos, irregulares e refugiados}

O Brasil desde o final dos anos 90 do século XX configura-se como área de expansão das migrações latino-americanas, reforçando as modalidades de tipo fronteiriço. Diversos são os casos de imigrantes oriundos da Colômbia, Bolívia, Paraguaia, Peru e da Venezuela em direção às áreas metropolitanas. Verifica-se o crescente fluxo de deslocamento humano. Essa busca por emprego e renda entre os países do Mercosulfinda por atender a demanda de mão de obra não qualificada dos países 
centrais. Os setores destinatários dessa mão de obra imigrante são o da agricultura, alimentação, construção, têxtil e vestuário. Exercem trabalhos mais pesados, indesejados e de maior risco, que, por vezes, a comunidade local se recusa a desempenhar.

Marcela Tomáz (2014, online), em estudo sobre fluxos migratórios e políticas públicas entre Brasil e Bolívia, aponta que a intensificação da migração pela busca de melhores condições de vida entre os países latino-americanos, não é díspar do que ocorre no contexto internacional. A proximidade geográfica e cultural, a maior facilidade para driblar a necessidade de documentos e vistos, a existência de redes sociais consolidadas, entre outros motivos, favorecem os deslocamentos sul-sul, que representam hoje parcela significativa das migrações do mundo.

Cumpre lembrar que os deslocados, em geral, oriundos de países vizinhos, transformam-se em imigrantes irregulares. Na maioria das vezes, a migração é feita a partir de redes montadas por agências de viagem ou atravessadores. O recrutamento ocorre por meio de anúncios em emissora de rádios locais que prometem bons salários com alimentação e alojamento incluídos. Em outros casos, o contato é feito diretamente pelo empregador que, não raro, acolhe também os familiares. Como em geral, os futuros imigrantes não possuem documentos de viagem, nem passaportes, o trajeto mais curto é evitado, sendo substituído por rotas onde há menor controle de imigração. Esses movimentos migratórios nas zonas fronteiriças acontecem com significativa intensidade e, desse modo resultam em irregularidade e por fim condições precárias e trabalho análogo ao de escravo.

No caso da Bolívia, a baixa expectativa de desenvolvimento que se origina da estrutura social e econômica, pela instabilidade política e pela miséria de determinadas regiões a tornam centro de emigração de mão de obra. Muitos desses bolivianos acabam sendo absorvido pelo trabalho irregular, muitas vezes escravo, da indústria têxtil paulista. Ressalta-se que a cidade de Corumbá, situada na fronteira Brasil-Bolívia, com as cidades bolivianas de Puerto Soarez e Puerto Quijarro, é local de alta vulnerabilidade a todos esses problemas fronteiriços. A Marcela Tomaz aponta que:

É grande o número de bolivianos atendidos pelo sistema de saúde brasileiro, como também é importante o número de estudantes bolivianos em Corumbá. A cidade recebe muitos turistas, cuja maioria destina-se ao turismo da pesca. Destaca-se o número elevado de profissionais do sexo, de brasileiros e bolivianos, assim como o consumo de drogas. (TOMÁZ, 2014, online).

Nesse sentido, nota-se que a entrada irregular de imigrantes pode estar vinculada a situações informais de trabalho. No primeiro bimestre de 2014, ocorreu denuncia sobre uma oficina que empregou imigrantes bolivianos e os mantinha em situação análoga à de escravos, em condições insalubres e irregulares de trabalho. Localizada na Zona Leste de São Paulo, essa oficina fabricava peças de roupas e as repassava para a marca M. Oficcer, (Globo notícias, 2014, online).Operação realizada pela Superintendência Regional do Trabalho e Emprego de São Paulo (SRTE/ 
SP), ${ }^{240} \mathrm{em}$ maio de 2014, resgatou trabalhadores bolivianos. Há manifestação do Ministério Público de São Paulo, pelo oferecimento de denúncia contra a empresa M. Officere sua terceirizada.

Nessa temática, compreende-se o trabalho acadêmico de Cibele Rizek, Isabel Georges e Carlos Freire da Silva (2010), no qual é descrita pesquisa de campo, de natureza exploratória, em forma de entrevista, realizada com o intuito de comparar a emigração boliviana em dois países do Cone Sul: Argentina e Brasil. Na entrevista foi coletado depoimento de imigrantes bolivianos que passaram por trabalhos informais em confecções no Brasil, bem como outras espécies de labor no território argentino.Os autores explicam que a emigração boliviana sucedeu a imigração de coreanos, no estado de São Paulo. A imigração, neste caso, concentrou-se para o trabalho (irregular) no setor de confecção e não resulta em inclusão social. Na Argentina o campo de trabalho é mais abrangente, os imigrantes passam por estádias irregulares, porémfindam por serem aceitos socialmente e passam a integrar a sociedade argentina.

Observa-se que no concernente à imigração boliviana, em 2005 foi realizado um acordo bilateral entre Brasil e Bolívia para regularização de imigrantes irregulares. Como se sabe, é escopo da Organização das Nações Unidas combater à imigração ilegal, já que ela contribui para o tráfico de seres humanos e diversos outros crimes decorrentes deste. No acordo realizado entre os países, os principais objetivos são a regularização do fluxo migratório e a promoção da integração entre os Estados. O acordo estabelece a imprescindível regularização para o gozo da igualdade de direitos entre nacionais e bolivianos.

Noutro viés, em que se refere às imigrações forçadas, é necessária explanação acerca dos refugiados. Segundo Márcia Morikawa (2006, p. 222) diferentemente do que ocorre aos estrangeiros, como os bolivianos irregulares, os refugiados não se encontram mais sobre a proteção de seu Estado de origem, e têm seu direito de liberdade mitigado, pois ficam sob a proteção especial do país acolhedor. De acordo com Paula Teixeira (2009), o refugiado é um tipo de migrante forçado. Migrantes forçados, segundo a autora, são aqueles que passam por alguma adversidade, ou necessidade em seu país de origem e se vêm forçados a imigrar. Destarte, o refugiado é considerado mais vulnerável, e, portanto, carece de imediata resolução.

A Convenção da Organização das Nações Unidas de 1951 - Estatuto do Refugiado, artigo $1^{\circ}$, traz a definição de refugiado, que deve ser interpretada em consonância com o Protocolo sobre o Estatuto dos Refugiados de Nova York de 31 de janeiro de 1967. Isto, porque o protocolo amplia a definição temporal de refugiado, passando a defini-lo independente da época em que ocorreram os motivos para busca do refúgio. No âmbito do Estado brasileiro, a Lei n. 9474 de 22 de julho de 1997 normatiza a promoção do estatuto.

${ }^{240}$ Disponível em: http://portal.mte.gov.br/imprensa/srte-sp-flagra-trabalho-escravo-na-m-officer.htm. Acessado em: 16.10.2014. 
Verifica-se, por conseguinte, que o refugiado não se confunde com o imigrante irregular, embora haja a possibilidade de em ambos os casos a imigração ser forçada. Não se encontra entre os quesitos para considerar o estrangeiro como refugiado propriamente dito, questões de ordem econômica, como crises dos sistemas financeiros, ou questões advindas de intempéries climáticas.

Segundo Graziele Ribeiro (2013, p. 37), o conceito estrito de refugiado no Brasil refere-se às pessoas que por motivo de perseguição política, religiosa, racial ou social tem a necessidade de sair de seu país de origem e refugiar-se em outro que o acolha. A autora elenca outras formas de migração forçada, referindo-se ao caso dos refugiados climáticos, aos que imigram por razões econômicas, devido à precariedade na efetivação de direitos básicos em suas nações, ou no caso de indivíduos que vivem em locais com conflitos armados internos.

Por consequência, nota-se que a situação dos bolivianos, que migram para o Brasil, em busca de melhores oportunidades, não se confunde com a dos haitianos. Segundo Relatório de Pesquisa, elaborado Organização Internacional para Migrações (2010, online), o fluxo de haitianos no Brasil iniciou-se em 2010. As adversidades do caso peculiar de imigração, causadas pela intempérie climática que atingiu o Haiti, decorreram da falta de previsão normativa e de políticas públicas adequadas ao caso.

Segundo dados do Ministério do Trabalho e Emprego (MTE) ${ }^{241}$ foram concedidos 9.000 vistos, em caráter humanitário, para haitianos, no período de 2011 à março de 2014. De acordo com relatório do Conselho Nacional de Imigração, "Estudos sobre a Migração Haitiana ao Brasil e Diálogo Bilateral" (2014), os haitianos chegaram ao Brasil pela fronteira com o Peru, e adentraram os estados do Amazonas e sobremaneira o Acre, especificamente, instalaram-se na cidade de Brasiléia.

Os haitianos vinham principalmente da cidade de Porto-Príncipe, devido aos terremotos ocorridos em 2010, que acarretaram consequências sociais e econômicas para o Haiti. Não se pode precisar o número de haitianos que entraram no Brasil, conforme explica o relatório do CNIg (2014), porém, tem-se uma noção do fluxo diante do número de vistos concedidos. Os haitianos foram considerados, pelo governo brasileiro como refugiados climáticos, contrariando o disposto no Decreto n. 70.946, de 07 de agosto de 1972,que não engloba essa categoria de refúgio. Por fim, a solução encontrada pelo CNIg foi conceder aos haitianos visto humanitário, com fulcro na Resolução Normativa $n^{\circ} 27$, de 25 de novembro de $1998^{242}$, em face

\footnotetext{
${ }^{241}$ Disponível em: http://portal.mte.gov.br/trab_estrang/estatisticas.htm. Acessado em: 16.10.2014.

${ }^{242}$ O CONSELHO NACIONAL DE IMIGRAÇÃO, instituído pela Lei $n^{\circ} 8.490$, de 19 de novembro de 1992, no uso das atribuições que lhe confere o Decreto $n^{\circ} 840$, de 22 de junho de 1993, resolve:"“Art. $1^{\text {o }}$ Serão submetidas ao Conselho Nacional de Imigração as situações especiais e os casos omissos, a partir de análise individual. $§ 1^{\circ}$ Serão consideradas como situações especiais aquelas que, embora não estejam expressamente definidas nas Resoluções do Conselho Nacional de Imigração, possuam elementos que permitam considerá-las satisfatórias para a obtenção do visto ou permanência.§ $2^{\circ}$ Serão considerados casos omissos as
} 
da ausência de previsão normativa para o caso específico dos refugiados climáticos. observa-se a seguir, tabela com o número de imigrantes haitianos que se encontram regularizados até março de 2014.

Tab. 1. Residência em caráter humanitário.

\begin{tabular}{l|l}
\hline Ano & Residência em caráter humanitário - número de vistos para Haitianos \\
\hline 2011 & 709 \\
\hline 2012 & 4856 \\
\hline 2013 & 2072 \\
\hline 2014 & 1541 \\
\hline
\end{tabular}

Fonte: BRASIL. Ministério do Trabalho e Emprego (2014).

A celeuma dos haitianos no Brasil revela a falta de política migratória consistente. Mas, mesmo que o Brasil possuísse um arcabouço jurídico-legal avançado, este não seria suficiente para lidar com a questão do afluxo de haitianos em seu território. O Brasil é um país de muitas contradições (políticas, sociais e econômicas) e o caminho para a regularização de um imigrante é burocrático e moroso. Soma-se a isso a falta de medidas de assistência social e de acolhimento local e até mesmo de acesso a políticas públicas. Ou seja, terminado o processo de regularização da migração, o desafio permanece para integrá-los na sociedade, pois existem poucas e pontuais políticas públicas de atendimento. (RODRIGUES, 2014, online).

Viviane Mozine Rodrigues (2014, online), em artigo sobre migrantes haitianos no Brasil, narra a saga pela a regularização da situação destes migrantes no Estado brasileiro. Os haitianos que chegaram ao Brasil tentaram o enquadramento no status de refúgio, entretanto, eles tiveram a sua solicitação negada, pois, conforme exposto anteriormente, não são considerados refugiados por não se incluírem nos requisitos, muito embora a lei brasileira considere que "devido à grave e generalizada violação de direitos humanos, é obrigado a deixar seu país de nacionalidade para buscar refúgio em outro país" dando interpretação ampla, na qual os haitianos poderiam ser reconhecidos como refugiados pelo governo brasileiro.

Ressalta-se que, no que se refere às situações como a dos haitianos, o Anteprojeto de 2014 prevê no artigo 28 a possibilidade de concessão de visto humanitário para os casos de imigrantes que passam em seus países situações de instabilidade institucional, calamidades causadas por intempéries climáticas e graves violações aos direitos humanos. Em que pese a subjetividade das hipóteses, o anteprojeto dispõe sobre o caso, enquanto que o Projeto de Lei n ${ }^{\circ}$ 5.655/09 permanece silente.

Diante dessas circunstâncias, constata-se que as situações dos haitianos e bolivianos é similar, na medida em que refugiados climáticos e trabalhadores irregulares precisam da proteção do Estado, principalmente da garantia políticas públicas

hipóteses não previstas em Resoluções do Conselho Nacional de Imigração." 
concretas visando a integração. No caso dos refugiados a concessão dos vistos se dá de modo peculiar, por inexistir a hipótese de catástrofes naturais na legislação. Já a regularização dos bolivianos, utilizados como exemplo, pode ocorrer por meio de legislação que permita a requisição de residência temporária. Estas leis, denominadas de "leis de anistia" são parte das políticas governamentais voltadas às migrações.

\subsubsection{As leis de anistia}

A despeito da existência de diversos vistos para entrada e permanência no Estado brasileiro, é possível a presença de imigrantes irregulares. A atual legislação que dispõe sobre estrangeiros no Brasil veda a legalização da estada de imigrante clandestino. Contudo, foram elaboradas leis de anistia que regularizam a situação dos irregulares atualizando a Lei n. 6.815 de 19 de agosto de 1980 (Estatuto do Estrangeiro).

De acordo com Graziele Ribeiro (2013, p. 55), devido às falhas presentes na estrutura normativabrasileira que dispõe sobre a entrada de estrangeiros e sua permanência, adotou-se a regularização da situação dos irregulares por intermédio da anistia. Esta solução, que deveria ser excepcional, tornou-se a regra, conforme se verifica da existência de três leis seguidas sobre o tema, no prazo médio de dez anos.

A primeira lei de anistia dos imigrantes irregulares foi a Lei n. 7.685 de 02 de dezembro de 1988 que possibilitava ao estrangeiro, em situação ilegal, a solicitação de registro provisório. A lei dispunha em seu artigo $2^{\mathrm{o} 243}$ que o estrangeiro teria os mesmo direitos e deveres relativos aos imigrantes temporários do artigo 13, inciso V da Lei n. 6.815/90244.

A Lei n. 9.675 de 29 de junho de 1998 veio a substituir a Lei n. 7.685/88, porém, apenas modificou a situação temporal. Assim, a anistia foi ampliada aos estrangeiros ilegais que adentraram o território brasileiro até a data de 29 de junho de 1998. Da mesma forma, embora seja mais específica em alguns aspectos a legislação seguinte, a Lei n. 11.961 de 02 de julho de 2009 permite a requisição de residência provisória por estrangeiro que tenha ingressado em $1^{\circ}$ fevereiro 2009.

243 “Art. $2^{\circ} \mathrm{O}$ registro provisório, a partir de sua concessão, assegura ao seu detentor permanência por até dois anos, com os mesmos direitos e deveres de estrangeiro possuidor de visto temporário, previsto no art. 13 , item $V$ da Lei $n^{0} 6.815$, de 19 de agosto de 1980 , inclusive: I - exercício de atividade remunerada; II - matrícula em estabelecimento de ensino; III - livre locomoção pelo território nacional”. (Grifou-se).

244 “Art. 13. O visto temporário poderá ser concedido ao estrangeiro que pretenda vir ao Brasil: I - em viagem cultural ou em missão de estudos; II - em viagem de negócios; III - na condição de artista ou desportista; IV - na condição de estudante; V - na condição de cientista, professor, técnico ou profissional de outra categoria, sob regime de contrato ou a serviço do Governo brasileiro; VI - na condição de correspondente de jornal, revista, rádio, televisão ou agência noticiosa estrangeira; VII - na condição de ministro de confissão religiosa ou membro de instituto de vida consagrada e de congregação ou ordem religiosa". (Grifou-se). 
Encontra-se em trâmite na Câmara dos Deputados, o Projeto de lei n. 6.300 de 30 de junho de 2013 para concessão de nova anistia aos imigrantes irregulares, de autoria do Deputado Junji Abe. A norma amplia o tempo para os estrangeiros que entraram no território nacional até a data de 30 de junho de 2013 e mantém as mesmas disposições da primeira lei de anistia. Porém, tais formas de regularização não podem ser isoladas, diante da necessidade de políticas públicas voltadas ao reconhecimento do estrangeiro como um sujeito de direitos e deveres.

Destarte, importa observar a crítica realizada por Rossana Reis (2011, p. 61), pois embora as leis de anistia demonstrem a vontade do governo brasileiro em tratar das questões dos imigrantes irregulares, revelam problema persistente que ainda não foi solucionado. A autora defende que o ideal é a promoção do Projeto de Lei 5.655/09 e dos acordos de livre circulação no sentido de integração do Brasil aos outros países, precipuamente os latino-americanos.

Cumpre lembrar, que o Projeto de Lei em análise enaltece o desenvolvimento nacional e assim prioriza os vistos de entrada aos imigrantes trabalhadores qualificados que agregarão alternativas ao crescimento econômico local. É possível, observar por meio de dados disponibilizados pelo Ministério do Trabalho e Emprego (MTE) que os três estados de maior concentração de trabalhadores imigrantes são: São Paulo, Rio de Janeiro e Ceará.

\subsection{A imigração regular no estado do Ceará}

No que concerne ao Nordeste brasileiro, constata-se que o Ceará tem se destacado no que diz respeito às imigrações voltadas ao trabalho e investimentos. Verifica-se que o estado traduz o escopo do projeto de legislação, no que se refere à imigração voltada ao desenvolvimento local. No estado do Ceará, conforme dados do Ministério do Trabalho e Emprego (MTE), a maioria dos imigrantes é formada por europeus, e desde 2012 verifica-se um aumento no número de sul-coreanos no estado cearense, conforme tabela a seguir:

Tab. 2. Nacionalidade - Imigrantes no Estado do Ceará.

\begin{tabular}{l|l|l|l|l|l|l|l}
\hline 2011 & \multicolumn{2}{l}{2012} & \multicolumn{2}{l}{2013} & \multicolumn{2}{l}{2014} \\
\hline ALEMANHA & 20 & $*$ & $*$ & ALEMANHA & 18 & $*$ & $*$ \\
\hline$*$ & $*$ & $*$ & $*$ & $*$ & $*$ & ÁUSTRIA & 3 \\
\hline CHINA & 32 & CHINA & 24 & CHINA & 22 & CHINA & 2 \\
\hline$*$ & $*$ & $\begin{array}{l}\text { CORÉIA DO } \\
\text { SUL }\end{array}$ & 297 & CORÉIA DO SUL & 667 & $\begin{array}{l}\text { CORÉIA DO } \\
\text { SUL }\end{array}$ & 192 \\
\hline DINAMARCA & 34 & $*$ & $*$ & $*$ & $*$ & $*$ & $*$ \\
\hline ESPANHA & 64 & ESPANHA & 74 & ESPANHA & 182 & ESPANHA & 14 \\
\hline EUA & 49 & EUA & 55 & EUA & 36 & EUA & 4 \\
\hline
\end{tabular}




\begin{tabular}{l|l|l|l|l|l|l|l}
\hline$*$ & $*$ & EQUADOR & 13 & $*$ & $*$ & EQUADOR & 3 \\
\hline FRANÇA & 17 & FRANÇA & 28 & FRANÇA & 53 & FRANÇA & 4 \\
\hline$*$ & $*$ & $*$ & $*$ & HOLANDA & 37 & $*$ & $*$ \\
\hline$*$ & $*$ & ÍNDIA & 62 & ÍNDIA & 20 & $*$ & $*$ \\
\hline ITÁLIA & 121 & ITÁLIA & 127 & ITÁLIA & 104 & ITÁLIA & 37 \\
\hline PORTUGAL & 94 & PORTUGAL & 169 & PORTUGAL & 163 & PORTUGAL & 26 \\
\hline$*$ & $*$ & REINO UNIDO & 16 & $*$ & $*$ & $*$ & $*$ \\
\hline ROMÊNIA & 36 & $*$ & & $*$ & $*$ & $*$ & $*$ \\
\hline SUIÇA & 23 & $*$ & $*$ & $*$ & $*$ & SUIÇA & 2 \\
\hline OUTROS & 166 & OUTROS & 96 & OUTROS & 86 & OUTROS & 12 \\
\hline Total & 656 & Total & 961 & Total & 1388 & Total & 299 \\
\hline
\end{tabular}

Fonte: BRASIL. Ministério do Trabalho e Emprego (2014).

De acordo com outros dados também do MTE constata-se que no Ceará o movimento de imigração está voltado, preponderantemente, ao desenvolvimento econômico da região, por intermédio de estímulo relacionado à entrada no estado de capital humano, ou seja, mão-de-obra qualificada bem como investimentos estrangeiros. Segundo dados do MTE (2014), foram investidos, só no primeiro quarto de 2014, R\$ 13.875.594,19, no Ceará, considerando-se o segundo estado brasileiro que mais recebe investimentos advindos do exterior.

Tab. 3. Profissional Estrangeiro com contrato de trabalho no Brasil - até 2 (dois) anos.

\begin{tabular}{l|l|l|l|l}
\hline UF & $\mathbf{2 0 1 1}$ & $\mathbf{2 0 1 2}$ & $\mathbf{2 0 1 3}$ & $\mathbf{2 0 1 4}$ \\
\hline SP & 2455 & 2891 & 2800 & 646 \\
\hline RJ & 1163 & 1446 & 1241 & 233 \\
\hline CE & 39 & $\mathbf{2 7 8}$ & 578 & 192 \\
\hline MG & 198 & 361 & 278 & 87 \\
\hline OUTROS & 760 & 856 & 1052 & 259 \\
\hline TOTAL & 4615 & 5832 & 5949 & 1417 \\
\hline
\end{tabular}

Fonte: Ministério do Trabalho e Emprego (2014).

Tab. 4. Autorização para trabalho permanente.

\begin{tabular}{l|l|l|l|l}
\hline UF & $\mathbf{2 0 1 1}$ & $\mathbf{2 0 1 2}$ & $\mathbf{2 0 1 3}$ & $\mathbf{2 0 1 4}$ \\
\hline SP & 1257 & 1393 & 1335 & 404 \\
\hline RJ & 392 & 414 & 440 & 119 \\
\hline
\end{tabular}




\begin{tabular}{l|l|l|l|l}
\hline CE & $\mathbf{2 1 3}$ & $\mathbf{2 6 7}$ & $\mathbf{2 7 7}$ & $\mathbf{7 1}$ \\
\hline BA & 120 & 174 & 168 & 40 \\
\hline OUTROS & 710 & 690 & 739 & 149 \\
\hline TOTAL & 2692 & 2938 & 2959 & 783 \\
\hline
\end{tabular}

Fonte: BRASIL. Ministério do Trabalho e Emprego (2014).

No que se refere aos investidores no Brasil, existe a Resolução Normativa n. 84 de 10 de fevereiro de 2010 do Conselho Nacional de Imigração (CNIg), órgão vinculado ao MTE. Ressalta-se, nesse sentido, que há necessidade do investidor manter o empreendimento, não o desfazendo assim que consegue o visto de autorização para permanência no Brasil. A empresa deve ser viável, gerar emprego e renda, bem como demonstrar produtividade (BOUCINHAS FILHO; BARBAS, 2013).

Tab. 5. Investidor - Pessoa física no estado do Ceará.

\begin{tabular}{l|l|l|l}
\hline 2011 & $\mathbf{2 0 1 2}$ & $\mathbf{2 0 1 3}$ & $\mathbf{2 0 1 4}$ \\
\hline 169 & 223 & 237 & 58 \\
\hline
\end{tabular}

Fonte: BRASIL. Ministério do Trabalho e Emprego (2014).

Nesse diapasão, nota-se que a situação do Ceará não se confunde com o estado do Acre, que recepcionou os haitianos refugiados climáticos, portanto, a política de imigração não possui caráter humanitário. $\mathrm{O}$ estado cearense destaca-se, em 2014, por meio dos números de vistos concedidos para trabalho temporário (192 autorizações), trabalho permanente (71 autorizações) e investimentos (58 autorizações).

Segundo a Organização Internacional para as Migrações - OIM, o migrante qualificado é aquele que por sua formação, aptidão e qualificaçãorecebe visto voltado para trabalho, ou seja, para contribuir com capital humano no país de entrada. No estado cearense, além dos estrangeiros investidores e com vínculo empregatício, segundo dados do MTE (2014), até final de março de 2014 passaram a residir no Ceará 29 (vinte e nove) imigrantes com formação técnica, mas sem vínculo laboral prévio, 12 (doze) capacitados para área de administração empresarial, 6 (seis) com formação artística e desportiva.

Verifica-se, ainda, no estado do Ceará, a partir do ano de 2012, um aumento de imigrantes de origem Sul-Coreana, principalmente para atuação no mercado de trabalho local. Nota-se, destarte, imigração voltada para "know-how", que exige do imigrante qualificação profissional. Cerca de mais de mil coreanos vivem no estado cearense, constituindo-se como a maioria dos imigrantes residentes no estado (SULCOREANOS..., 2013, online).

Por intermédio dos dados fornecidos pelo MTE constata-se que os vistos de caráter humanitário não representam contingente no estado do Ceará, em contra- 
partida, os vistos concedidos para trabalho, permanente ou temporário, ou mesmo para investidores, é relativamente alto. Desta forma, enquadra-se o estado nordestino entre os que mais recebem imigrantes para finalidades laborais.

Pondera-se, portanto, que as imigrações que ocorrem hodiernamente não possuem o escopo similar ao das imigrações ocorridas em meados dos séculos XIX e XX, haja vista as diferenças contingenciais e temporais. Destarte, torna-se imprescindível analisar os objetivos dos atuais imigrantes e avaliar as necessidades de políticas públicas voltadas à sua adaptação no Estado brasileiro, enquanto receptor de estrangeiros, que nem sempre são regulares e/ou capacitados.

\section{Politicas públicas migratórias}

Os países desenvolvidos têm a visão de que a política imigratória tem como fundamento o controle de fluxo de imigrantes. A. Zolberg (2006) argumenta que a ausência de controle de fronteiras dos países destinatários de migrantes resultaria em massivo fluxo de migrantes em busca de trabalho, benefícios sociais e segurança, e por consequência ocorreria desequilíbrio interno e descontrole sobre as funções estatais e sociais. Observa ainda o autor, que os bens públicos nos países desenvolvidos constituem parte importante da renda de sua população, haja vista que foram construídos e são mantidos pelos tributos pagos pelos trabalhadores, e na conjuntura da imigração, esses bens seriam repartidos com aqueles que não contribuíram e que não compreendem os valores históricos, culturais e sociais.

Ressalta-se que, sob o viés do pensamento de Estado Nação, a política migratória prioriza o escopo de garantir o crescimento econômico do país, assim como proteger o desenvolvimento humano dos cidadãos nacionais. Nessa vertente empreende ações que garantam a segurança física, a manutenção de empregos e a valorização da cultura. Nesse diapasão, verifica-se que a preocupação com os direitos humanos dos imigrantes, na amplitude de direitos internacionais, não são preponderantes.

Pode-se afirmar que, no auge do liberalismo econômico da segunda metade do Século XX, a globalização econômica e os mercados transnacionais contribuíram para a diminuição do preconceito com o trabalhador estrangeiro, haja vista que a oferta de trabalho superava aquela de mão de obra em diferentes setores. Para a economia mundial não importa quem produz, ou aonde é produzida a mercadoria, contrário senso, revela-se essencial identificar o mercado consumidor. Nesse viés, intensa foi a imigração nas décadas de 1980 a 2000. Já a crise de 2008 e suas consequências restabeleceram as divergências entre nacionais e estrangeiros e fizeram retornar políticas de proteção aos trabalhadores nacionais e acirramento contra os imigrantes.

Thimothy Hatton e Jeffrey Williamson (2005) analisam a crescente hostilidade dos países considerados, pelo Banco Mundial, com economias de alta renda 
aos imigrantes. Estes países são membros da Organização para a Cooperação e Desenvolvimento Económico (OCDE). Esse organismo internacional tem como objetivos:apoiar o crescimento econômico duradouro; desenvolver o emprego; aumentar o nível de vida; manter a estabilidade financeira; ajudar os outros países a desenvolverem as suas economias; contribuir para o crescimento do comércio mundial. Os autores identificaram três pilares desse sentimento de rejeição aos trabalhadores imigrantes: 1) Preocupação com a competição no mercado de trabalho interno; 2) temor de desequilíbrio fiscal, entre receitas inerentes aos auxílios governamentais próprios dos Estados de bem estar social, 3) preconceito cultural.

André Luiz Siciliano (2013) em dissertação de mestrado do Instituto de Relações Internacionais da Universidade de São Paulo alerta para o fato de que os países que privilegiam a imigração qualificada têm menos problemas com a adaptação desses imigrantes, em detrimento daqueles países que permitem a entrada de imigrantes com baixa capacitação técnica.

É possível afirmar que não são novas as conclusões da economia política do Século XXI, quando identificam que os países ricos exportam produtos realizados mediante utilização de conhecimento e técnicas bem desenvolvidas e que importam mercadorias oriundas de produção com mão-de-obra pouco qualificada, e assim os países pobres exportam produtos intensivos com força de trabalho e importam produtos industrializados, e nesse contexto, remetem imigrantes pouco qualificados e recebem imigrantes qualificados. Essa realidade já se fazia presente no Brasil Colônia, quando Portugal exportava vinho e importava produtos originários do processo de industrialização da Inglaterra.

Cumpre lembrar que a política imigratória a ser implementada pelo Estado deverá observar: 1) Os objetivos de desenvolvimento do seu mercado de trabalho, e da economia nacional; 2) Minimizar e otimizar os gastos públicos; 3) Proporcionar políticas de segurança nacional e de proteção aos bens e espaços públicos; 4) Conciliar o desenvolvimento local com as regras de cooperação internacional e respeito aos direitos humanos; 5) Manter, diante da Justiça do Trabalho, as regras da Teoria Justrabalhista, haja vista que inibe o trabalho em condições análogas à de escravo ou prestado de forma irregular, e assim penaliza o empregador; 6) Adotar ações que facilitem a integração do imigrante na sociedade local. Nessa vertente deve incentivar a aculturação e a troca de experiências e de valores, e nesse viés, possibilita a acomodação entre diferentes.

Vale a pena ponderar para o bom senso dos administradores locais, assim seguindo o princípio do paralelismo, o executivo nas esferas nacional, estadual e municipal deverá ter competências concorrentes para que a política de imigração se efetive com sucesso, posto que, a integração dos migrantes ocorre no âmbito local e os gestores das municipalidades são atores da execução da política nacional.

Eytan Meyers (2004) divide em três pilares o foco das políticas imigratórias, aquelas que partem da análise internacional e dos acordos multilaterais sobre a 
política de imigração entre os países receptores e os emissores, que buscam analisar as diferenças culturais entre nacionais e imigrantes e que observam a qualificação para o trabalho a ser desenvolvido e a possível competição econômica entre os nacionais e os imigrantes.

\subsection{Políticas públicas imigratórias no Brasil: direitos humanos ou De- SENVOLVIMENTO?}

Os portugueses residentes no Brasil, à época colonial, nunca tiveram bons olhos para abertura das fronteiras com a finalidade de povoamento da colônia por outras nacionalidades, que não fosse alusitana. Lucia Lippi Oliveira (2001, e-book), na obra $O$ Brasil dos imigrantes, relata que as políticas públicas brasileiras, a partir do século XIX, voltadas para imigração oscilavam sempre entre momentos de abertura das fronteiras para mão de obra estrangeira e momentos xenofobia exacerbada por uma legislação extremamente restritiva.

Em 1808 foi promulgada a lei que permitia aos estrangeiros a propriedade de terras no Brasil. O governo imperial subvencionava a formação de núcleos coloniais de agricultores em suas terras devolutas e em sistema de pequena propriedade, como foi o caso dos alemães no Sul e Sudeste. Porém só em meados do século começaram a chegar imigrantes para suprir a carência de mão de obra nos cafezais paulistas, passando então a ser empregados nessa monocultura de exportação. A subvenção também se altera, deixa de ser exclusiva responsabilidade do governo imperial para incluir também os governos provinciais e a iniciativa privada. Companhias internacionais de imigração se encarregam de recrutar, transportar e instalar os novos imigrantes no Brasil (IBGE, 2000).

No entanto, segundo EmiliaViotti da Costa (1998, p. 119) o governo não encontrava terras devolutas em condições favoráveis para localizar núcleos coloniais, ficando obrigado a situá-los em zonas improdutivas e inconvenientes, ou a despender verba com a aquisição de terras. Além do entrave ao desenvolvimento da pequena propriedade, outros motivos existiam a prejudicar o estabelecimento de uma corrente imigratória para o Brasil, entre os quais, a grande atração exercida nessa época pelos Estados Unidos, que ofereciam condições muito mais favoráveis do que as nossas, e para os quais era canalizada a maior parte da imigração europeia.

Ao verificar o cenário brasileiro, no que é referente ao fluxo de pessoas, Neide Parrato et al. (2011) dissertam que a partir de 2000 ocorreu uma mudança de perfil dos imigrantes. Passaram a retornar ao Brasil, os emigrantes brasileiros da década de 80 , bem como adentraram no território, de forma regular ou não, imigrantes advindos de países em desenvolvimento. Neste caso, tem-se o exemplo dos bolivianos e haitianos, estes chamados de refugiados climáticos.

A fiscalização dos vistos e sua liberação se dá por intermédio da Polícia Federal. Contudo, nos casos que envolvem direitos trabalhistas, o Ministérios do 
Trabalho e Emprego (MTE), por meio do Conselho Nacional de Imigração (CNIg) é o principal responsável pelas políticas imigratórias no Brasil, principalmente, nos casos, em que a legislação é lacunosa, e nãoprevê solução, por exemplo para a questão dos refugiados climáticos.

Percebe-se que, apesar, da realidade brasileira demonstrar a entrada de imigrantes não qualificados, as políticas imigratórias e a legislação nacional estão voltadas aos imigrantes com qualificação profissional. Neide Parrato (2011, p. 212) explica que o imigrante qualificado é aquele que possui nível superior completo ou incompleto. Os autores dissertam que a política imigratória volta-se nesse caso para atração de capital humano com o fito de atingir desenvolvimento tecnológico e econômico. Daí a criação de mecanismos de facilitação para mobilidade e preenchimento de lacunas no mercado de trabalho brasileiro.

Por outro lado, fica evidenciada a falta de políticas públicas voltadas à conciliação entre os Direitos humanos dos imigrantes e o Desenvolvimento local. Nesse sentido, observa-se que o CNIg, desde 2010, propôs um plano de política pública, Política Nacional de Imigração e Proteção do Trabalhador Imigrante, que ainda não foi posto em prática pelo governo federal. Os autores ressaltam ainda, que o Projeto de Lei n. 5.655 de 20 de julho de 2009, em trâmite no Congresso Nacional, volta-se mais à proteção nacional e trata a imigração irregular do mesmo modo que o Estatuto do Estrangeiro.

Segundo dados do MTE (2014), que se verificam na tabela abaixo, o maior contingente de imigrantes, que adentram o Brasil de forma regular, possui certo grau de qualificação. Os números exemplificam a noção de que a política imigratória brasileira preocupa-se com o desenvolvimento por intermédio do capital humano, ou seja, entrada de indivíduos qualificados para o mercado de trabalho.

Tab. 6.Autorização concedidas para entrada no Brasil - Estrangeiros por nível de escolaridade

\begin{tabular}{l|l|l|l|l}
\hline Nível de escolaridade & 2011 & 2012 & 2013 & 2014 \\
\hline Superior Completo & 38.474 & 37381 & 34073 & 6413 \\
\hline Ensino Médio & 23470 & 25934 & 24691 & 3319 \\
\hline Mestrado & 1427 & 1964 & 1827 & 424 \\
\hline Pós-graduação & 673 & 908 & 825 & 165 \\
\hline Doutorado & 220 & 314 & 311 & 100 \\
\hline Superior Incompleto & 471 & 289 & 271 & 32 \\
\hline $\begin{array}{l}\text { Ensino Fundamental Com- } \\
\text { pleto }\end{array}$ & 194 & 288 & 252 & 55 \\
\hline Ensino Médio Incompleto & 152 & 129 & 84 & 12 \\
\hline $\begin{array}{l}\text { Ensino Fundamental Incom- } \\
\text { pleto }\end{array}$ & 20 & 12 & 52 & 9 \\
\hline
\end{tabular}




\begin{tabular}{l|l|l|l|l}
\hline Não Informado & 3976 & 1 & 1 & 0 \\
\hline Total & 69077 & 67220 & 62387 & 10529 \\
\hline
\end{tabular}

Fonte: BRASIL. Ministério do Trabalho e Emprego (2014).

A Política Nacional de Imigração disposta pelo CNIg (2010) tem o escopo, precípuo, de estabelecer princípios, diretrizes e estratégias voltados aos fluxos migratórios internacionais. A finalidade perpassa a orientação de órgãos, instituições e entidades, estatais ou não, que atuam na seara das imigrações. Verifica-se que a política, proposta pelo plano, tenta conciliar proteção dos Direitos Humanos, tanto dos imigrantes, quanto dos brasileiros emigrantes que retornam ao país, com o Desenvolvimento econômico, social, humano, cultural, tecnológico e político, na esfera local.

Além do objetivo de regularizar a situação das migrações, a política acima proposta, possui as seguintes diretrizes:

1.migração e desenvolvimento local como direitos fundamentais;

2. critérios para admissão no território nacional,não-arbitrários e não-discriminatórios;

3.tratamento paritário e isonômico aos estrangeiros;

4.integração regional, principalmente dos países latino-americanos;

5.desburocratização do sistema, com condições mais humanas de tratamento e celeridade nos procedimentos;

6.inserção dos imigrantes e dos brasileiros emigrantes que retornam ao país.

Relata-se também que em 30 de abril de 2010, foi enviado ao Legislativo, pelo Ministério das Relações Exteriores, mensagem, tencionando a ratificação da Convenção Internacional sobre os trabalhadores migrantes e seu comitê, adotada pela Resolução n 45/158 da Assembleia Geral da Organização das Nações Unidas (ONU) em 18 de dezembro de 1990.

A convenção acima mencionada tenciona garantir tratamento igualitário ao trabalhador migrante e seus familiares, evitando, desta forma, que os imigrantes sejam discriminados ou diferenciados de forma negativa pelo Estado receptor. A Convenção estabelece, em seu artigo $7^{0245}$, que os Estados que ratificarem-na, comprometem-se a efetivar os direitos humanos de todos os trabalhadores, imigrantes regulares ou não.

245 “Artigo 7. Os Estados Partes comprometem-se, de acordo com os instrumentos internacionais relativos aos direitos humanos, a respeitar e a garantir os direitos previstos na presente Convenção a todos os trabalhadores migrantes e membros da sua família que se encontrem no seu território e sujeitos à sua jurisdição, sem distinção de qualquer tipo em relação a sexo, raça, cor, idioma, religião ou convicção, opinião política ou outra, origem nacional, étnica ou social, nacionalidade, idade, posição econômica, patrimônio, estado civil, nascimento ou de qualquer outra situação". 
Verifica-se, portanto, que existem propostas de políticas públicas voltadas aos fluxos migratórios, seja com foco nos estrangeiros imigrantes, quanto no caso de brasileiros que retornam. Contudo, como se denota da crítica realizada por Deyse Ventura e Paulo Illes (2012, online) não háefetivação de política imigratória determinada no Estado brasileiro. Desta forma, não se sabe se a política imigratória no Brasil está voltada à proteção dos Direitos humanos dos estrangeiros, independente de sua regularidade, ou se foca-se na efetivação do desenvolvimento nacional. Os autores alertam sobre a possibilidade de criar-se uma política imigratória seletiva, preferindo-se determinados tipos de imigrantes a outros.

Nesse viés, André Siciliano (2013, p. 52) disserta que, embora existam políticas voltadas à imigração e emigração no Brasil, basicamente realizadas pelo CNIg, não há uma política migratória objetiva, com finalidade de coordenação dos diversos casos que envolvem a migração. As políticas não podem ser analisadas de modo isolado e particular, conforme salienta Rossana Reis (2011, p. 64), deve existir um conjunto de ações, precipuamente, voltado ao combate do narcotráfico, contrabando, tráfico de pessoas etc. Segundo a autora a política imigratória não pode olvidar-se das fronteiras brasileiras.

\section{Conclusão}

Diante do exposto, no presente trabalho acadêmico, denota-se que o Estado brasileiro varia, em determinados momentos históricos, como país de imigração e emigração. Formado, precipuamente por estrangeiros, o Brasil, caracteriza-se pela diversidade de culturas e etnias. Nesse viés, nota-se que a grande maioria dos brasileiros é descendente de imigrantes.

Contudo, verifica-se, enfim, que apesar da formação histórica, atualmente, o Brasil demonstra política imigratória voltada à entrada de estrangeiros que tenham o escopo de investir ou trabalhar (mão de obra qualificada). Haja vista que a inserção de capital humano, principalmente em setores do mercado de trabalho escassos de profissionais com especialidade e qualificação, que fomentem o desenvolvimento local.

Constata-se no decorrer do artigo que, apesar da legislação brasileira repelir a imigração irregular, esta, de fato ocorre, e acaba por causar a discrepância de tratamento entre os imigrantes que adentram o território nacional. Exemplifica-se com o caso dos bolivianos, que entram no Brasil de modo irregular e passam a ser mão-de-obra informal e barateada, especificamente nas confecções.

Nesse sentido, verifica-se também, a situação dos haitianos, que se estabeleceram no Brasil com visto humanitário, diante da lacuna legislativa quanto à questão dos "refugiados climáticos". Estes imigrantes, que saíram do Haiti de modo forçado, devido à necessidade causada por intempérie climática, não se confundem com os irregulares. Porém, a sua inserção no Estado brasileiro, da mesma forma 
depende da promoção de políticas públicas imigratórias.

Noutro viés, analisa-se a imigração no estado do Ceará, por intermédio de dados do Ministério do Trabalho e Emprego, constata-se que o estado nordestino, recebeu entre 2011 e inícios de 2014, trabalhadores imigrantes qualificados. O estado exemplifica, destarte, o objetivo do Projeto de Lei n. 5.655 de 20 de julho de 2009, que se caracteriza pela busca por desenvolvimento local.

Por outro lado, pondera-se sobre a necessidade de conciliação entre a busca pelo desenvolvimento econômico, cultural, tecnológico e social, e o tratamento paritário entre estrangeiros e nacionais. Nesta perspectiva, apresentam-se o PL n. 5.655/09, bem como o Anteprojeto de 2014, elaborado por comissão indicada pelo Ministério da Justiça.As duas proposições normativas visam atualizar o ordenamento jurídico brasileiro, diante da incompatibilidade atual do Estatuto do Estrangeiro.

À falta de legislação atualizada combina-se à necessidade de política migratória voltada às situações reais no Estado brasileiro. Atualmente, o Conselho Nacional de Imigração (CNIg), vinculado ao MTE, é responsável por diversas situações de migrações. Porém, apesar da elaboração, conforme se explanou alhures de plano de políticas públicas voltadas aos migrantes, não há posicionamento do Governo Federal.

Por fim, pode-se concluir que apesar da existência de proposições normativas, bem como políticas públicas, o Brasil não tem definição concreta e homogênea quanto ao tratamento dos estrangeiros, compreendendo-se estes como aqueles que adentram e circulamno território nacional, independente da regularidade.

Portanto, não é suficiente a promulgação de Leis de anistias, ou políticas imediatistas e pontuais para a definição das situações relacionadas às migrações no Estado brasileiro. Neste sentido, conclui-se pela necessidade de inserir o tema no âmbito acadêmico com o escopo de compreender os fluxos migratórios, tanto de entrada como saída do Brasil, com foco na análise e sistematização entre normas existentes, políticas e órgãos responsáveis pelas migrações, e respectivos aprimoramentos.

Já àcomunidade internacional carece fomentar um sistema adaptável de migração internacional que responda às necessidades e à realidade econômica e social do Século XXI. Essa política internacional tem o escopo de propor ações que superem:

1) $O$ temor com a competição no mercado de trabalho interno e assim a capacitação e a formação de capital humano;

2) A angústia do planejamento fiscal e orçamentárioque resultem em desequilíbrio fiscal, entre receitas inerentes aos auxílios governamentais próprios dos Estados de bem estar social,

3) Visões distorcidas entre integração, acomodação e preconceito cultural, com a respectiva promoção dos direitos humanos. 
Em conclusão, reflete-se,por meio dessa pesquisa, acerca da conciliação entre os Direitos Humanos dos migrantes, a soberania nacional, relacionada ao desenvolvimento local, bem como a integração regional, principalmente com os países latino-americanos, tanto com relação aos fronteiriços como imigrantes do continente, ainda que de países não limítrofes. Nessa vertente de pensamento, compreende-se que a reformulação da legislação e efetivação de políticas imigratórias adequadas e a sua promoção eficaz são fundamentais à preservação dos direitos e consecução do crescimento econômico e desenvolvimento humano.

\section{REFERÊNCIAS}

BAENIGER, Rosana. O Brasil na rota das migrações latino-americanas. In: BAENIGER, Rosana (Org.). Imigração Boliviana no Brasil. Disponível em: http://www. nepo.unicamp.br/textos/publicacoes/livros/bolivianos/livro_bolivianos.pdf. Acessado em: 19.09.2014.

BALTAR, Paulo. Política econômica, emprego e política de emprego no Brasil. Estudos avançados, São Paulo, v.28, n. 81, pp. 95-114, 2014.

BERTOLIN, Patrícia Tuma Martins;TUPIASSÚ, Alessandra de Cássia Fonseca Tourinho. Os direitos sociais trabalhistas como direitos fundamentais naConstituição de 1988, sua eficácia e a proibição do retrocesso social. Âmbito Jurídico, Rio Grande ,ano XIV,n. 88, maio 2011. Disponível em: http:/www.ambito-juridico.com.br/ site/?n_link=revista_artigos_leitura\&artigo_id $=9198 \&$ revista_caderno $=25$. Acessado em: $15.10 .201 \overline{4}$.

BOUCINHAS FILHO, Jorge Cavalcanti; BARBAS, Leandro Moreira Valente. Migração de trabalhadores para o Brasil: aspectos teóricos e práticos. São Paulo: Saraiva, 2013.

BRASIL. Compromisso de Montevidéu sobre Migrações e Desenvolvimento, 05 de novembro de 2006.Disponível em: http://www.mte.gov.br/trab_estrang/compromisso_montevideu.pdf. Acessado em: 10.08.2014.

BRASIL. Conselho Nacional de Imigração - CNIg. Política nacional de imigração e proteção ao trabalhador migrante, 18 de agosto de 2010. Disponível em: http:// portal.mte.gov.br/cni/. Acessado em: 11.08.2014.

BRASIL. Conselho Nacional de Imigração - CNIg. Resolução Normativa n. 27, de 25 de novembro de 1998. Disponível em: http://portal.mte.gov.br/trab_estrang/resolucao-normativa-n-27-de-25-11-1998.htm. Acessado em: 11.08.2014.

BRASIL. Conselho Nacional de População e Desenvolvimento. Migração internacional. Cadernos temáticos. Disponível em: http://www.cnpd.gov.br/cnpd/pg-cader- 
nos-tematicos/migracao-internacional/. Acessado em: 25.05.2014.

BRASIL. Constituição (1824). Constituição Politica do Império do Brazil, de 25 de março de 1824. Disponível em: http://www.planalto.gov.br/ccivil_03/constituicao/ constituicao24.htm. Acessado em: 13.09.2014.

BRASIL. Constituição (1891). Constituição da República dos Estados Unidos do Brasil, de 24 de fevereiro de 1891. Disponível em: http://www.planalto.gov.br/ccivil_03/constituicao/Constituicao91.htm. Acessado em: 13.09.2014.

BRASIL. Constituição (1934). Constituição da República dos Estados Unidos do Brasil, de 16 de julho de 1934. Disponível em: http://www.planalto.gov.br/ccivil_03/ constituicao/Constituicao34.htm. Acessado em: 13.09.2014.

BRASIL. Constituição (1937). Constituição dos Estados Unidos do Brasil, de 10 de novembro de 1937. Disponível em: http://www.planalto.gov.br/ccivil_03/constituicao/constitui\%C3\%A7ao37.htm. Acessado em: 13.09.2014.

BRASIL. Constituição (1946). Constituição dos Estados Unidos do Brasil, de 18 de setembro de 1946. Disponível em: http://www.planalto.gov.br/ccivil_03/constituicao/constitui\%C3\%A7ao46.htm. Acessado em: 14.09.2014.

BRASIL. Constituição (1967). Constituição da República Federativa do Brasil, de 24 de janeiro de 1967. Disponível em: http://www.planalto.gov.br/ccivil_03/constituicao/constituicao67.htm. Acessado em: 14.09.2014.

BRASIL. Constituição (1988). Constituição da República Federativa do Brasil, de 05 de outubro de 1988.41. ed. São Paulo: Saraiva, 2008.

BRASIL. Constituição da República Federativa do Brasil de 1988. Disponível em: http://www.planalto.gov.br/ccivil_03/constituicao/constituicao.htm. Acessado em: 08.08.2014.

BRASIL. Decreto n.19.482, de 12 de Dezembro de 1930. Disponível em: http:// www2.camara.leg.br/legin/fed/decret/1930-1939/decreto-19482-12-dezembro1930-503018-republicacao-82423-pe.html. Acessado em: 09.09.2014.

BRASIL. Decreto n. 70.946, de 07 de agosto de 1972 - Protocolo sobre Estatuto dos Refugiados, concluídos em Nova York, a 31 de Janeiro de 1967. Disponível em: http://legis.senado.gov.br/legislacao/ListaTextoIntegral.action?id=96932\&nor$\mathrm{ma}=121310$. Acessado em: 09.08.2014.

BRASIL. Instituto Brasileiro de Geografia e Estatística. Brasil: 500 anos (2000). Disponível em: http://brasil500anos.ibge.gov.br/. Acessado em: 10.08. 2014.

BRASIL. Lei $n$. 11.961, de 02 de julho de 2009. Disponível em: http:/www.planalto. gov.br/ccivil_03/_Ato2007-2010/2009/Lei/L11961.htm. Acessado em: 07.08.2014.

BRASIL. Lei n. 6.815, de 19 de agosto de 1980 (Estatuto do Estrangeiro). Disponível 
em: http://www.planalto.gov.br/ccivil_03/leis/16815.htm. Acessado em: 08.08.2014. BRASIL. Lei $n$. 6.924, de 29 de junho de 1981. Disponível em: http:/www2.camara.leg.br/legin/fed/lei/1980-1987/lei-6924-29-junho-1981-366131-norma-pl.html. Acessado em: 21.09.2014.

BRASIL. Lei n. 7.685, de 02 de dezembro de 1988. Disponível em: http://presrepublica.jusbrasil.com.br/legislacao/128158/lei-7685-88. Acessado em: 07.08.2014.

BRASIL. Lei n. 9.474, de 22 de julho de 1997. Disponível em: http://www.planalto. gov.br/ccivil_03/Leis/L9474.htm. Acessado em: 09.08.2014.

BRASIL. Lei n. 9.675, de 29 de junho de 1998. Disponível em: http://presrepublica. jusbrasil.com.br/legislacao/111200/lei-9675-98. Acessado em: 07.08. 2014.

BRASIL. Ministério da Justiça. Portaria n. 2.162, de 2013 (Anteprojeto de Lei das Migrações). Disponível em: http://www.cdhic.org.br/wp-content/uploads/2014/05/ Anteprojeto-Nova-Lei-de-Migra\%C3\%A7\%C3\%B5es.pdf. Acesso em: 15.09.2014.

BRASIL. Ministério da Justiça. Triplica o número de estrangeiros em busca de refúgio no Brasil. Portal do Ministério da Justiça. Disponível em: $\quad$ http://portal.mj.gov.br/main.asp?View=\%7BBB799FA1-9499-42CF - B A 8 D - C D C B 8 F F B 5 A 4 F $\% 7$ D \& Tea $m \&$ param $s=i$ te $m$ I D = \% 7 B 60D6A533=9-84B431-A9859-0-7710493 A 17F 7\%D; \& UIPartUID\%7B2218FAF9-5230-431C-A9E3-E780D3E67DFE\%7D. Acessado em: 25.05. 2014.

BRASIL. Ministério das Relações Exteriores. Mensagem n. 696 de 13 de dezembro de 2010. Convenção Internacional sobre os trabalhadores migrantes e seu comitê. Resolução 45/158 da Assembleia-Geral da Organização das Nações Unidas de 18 de dezembro de 1990. Disponível em: http://www.camara.gov.br/sileg/integras/917816. pdf. Acessado em: 11.08.2014.

BRASIL. Ministério do Trabalho e Emprego - MTE. Base estatística geral - Detalhamento das autorizações concedidas pelo CNIg (Conselho Nacional de Imigração), 31 mar. 2014. Disponível em: http://portal.mte.gov.br/trab_estrang/estatisticas. htm. Acessado em: 02.07.2014.

BRASIL. Ministério do Trabalho e Emprego - MTE. Projeto "Estudos sobre a Migração Haitiana ao Brasil e Diálogo Bilateral", CNIg (Conselho Nacional de Imigração), Belo Horizonte, fev. 2014. Disponível em: http://portal.mte.gov.br/lumis/ portal/file/fileDownload.jsp?fileId=8A7C816A45B266980145DCAB8EF42233 Acessado em: 16.10.2014.

BRASIL. Tribunal Regional do Trabalho. Recurso Ordinário n. 1553620115020/SP, 16 maio 2013. Disponível em: http://trt-2.jusbrasil.com.br/jurisprudencia/24682789/ recurso-ordinario-ro-1553620115020-sp-20130015834-trt-2. Acessado em: 


\subsubsection{4.}

BRASIL. Decreto-lei n. 5.452, de $1^{\circ}$ de maio de 1943 (Consolidação das Leis Trabalhistas). Disponível em: http://www.planalto.gov.br/ccivil_03/decreto-lei/del5452. htm. Acessado em: 15.10.2014.

BRASIL. Tribunal Regional do Trabalho. Recurso Ordinário n. 1553620115020/SP, 16 maio 2013. Disponível em: http://trt-2.jusbrasil.com.br/jurisprudencia/24682789/ recurso-ordinario-ro-1553620115020-sp-20130015834-trt-2. Acessado em: 15.10.2014.

BRASIL. Decreto-lei n. 5.452, de $1^{\circ}$ de maio de 1943 (Consolidação das Leis Trabalhistas). Disponível em: http://www.planalto.gov.br/ccivil_03/decreto-lei/del5452. htm. Acessado em: 15.10.2014.

BRASIL. Ministério do Trabalho e Emprego - MTE. Base estatística geral - Detalhamento das autorizações concedidas pelo CNIg (Conselho Nacional de Imigração), 31 mar. 2014. Disponível em: http://portal.mte.gov.br/trab_estrang/estatisticas. htm. Acessado em: 02.07.2014.

BRASIL. Ministério do Trabalho e Emprego - MTE. Conselho Nacional de Imigração - CNIg. Resolução normativa n. 84 de 10 de fevereiro de 2010. Disponível em: http://portal.mte.gov.br/data/files/FF8080812BA5F4B7012BA713454612E5/ rn_20090210_84.pdf. Acessado em: 08.07.2014

BRASIL. Ministério do Trabalho e Emprego - TEM. Conselho Nacional de Imigração - CNIg. Acordo de regularização migratória Brasil/Bolívia, 15 de agosto de 2005. Disponível em: http://portal.mte.gov.br/data/files/FF8080812D0A02C0012D0DF379886073/acordo.pdf. Acessado em: 15.09.2014.

BRASIL. Ministério do Trabalho e Emprego. Base estatística - Autorizações concedidas pela CGIg para trabalho permanente - CNIg (Conselho Nacional de Imigração), 31 mar. 2014. Disponível em: http://portal.mte.gov.br/trab_estrang/estatisticas. htm. Acessado em: 02.07.2014.

BRASIL. Ministério do Trabalho e Emprego. Base estatística - Autorizações concedidas pela CGIg para trabalho temporário - CNIg (Conselho Nacional de Imigração), 31 mar. 2014. Disponível em: http://portal.mte.gov.br/trab_estrang/estatisticas. htm. Acessado em: 02.07.2014.

BRASIL. Projeto de Lei n. 5.655 de 20 de julho de 2009. Disponível em: http:// www.camara.gov.br/proposicoes Web/fichadetramitacao?idProposicao $=443102$. Acessado em: 07.08.2014

BRASIL. Projeto de Lei n. 6.300 de 30 de junho de 2013. Disponível em: http:// www.camara.gov.br/proposicoes Web/fichadetramitacao?idProposicao $=591068$. Acessado: 07.08.2014. 
CARVALHO, Maximiliano Pereira de; JUNQUEIRA, Fernanda Antunes Marques. $\mathrm{O}$ trabalho e o imigrante em situação irregular: à espera de uma absolvição. Panóptica, Vitória, v.8, n.1 (n. 25), pp. 158-190, 2013.

COSTA, EmíliaViottida. Da senzala à colônia. 4.ed. São Paulo: Fundação UNESP, 1998.

COUTINHO, Aldacy Rachid.Educação e trabalho: uma questão de direitos humanos. In: SILVEIRA, Rosa Maria Godoy et al. (Org.). Educação em direitos humanos: fundamentos teórico-metodológicos. João Pessoa: Universitária/UFPB, 2007. Disponível em: http://www.dhnet.org.br/dados/livros/edh/br/fundamentos/index.htm. Acessado em: 15.10.2014.

DOLINGER, Jacob. Direito internacional privado: parte geral. 9. ed. Rio de Janeiro: Renovar, 2008.

FISCAIS flagram bolivianos em situação semelhante à escravidão em SP. Globo notícias (G1), 16 maio 2014. Disponível em: http:/g1.globo.com/sao-paulo/noticia/2014/05/fiscais-flagram-bolivianos-em-situacao-semelhante-escravidao-em-sp. html. Acessado em: 08.08.2014.

FRANCISCO, Papa. Mensagem do Santo Padre Francisco para o Dia Mundial do Migrante e do Refugiado, 05 de agosto de 2013. Disponível em: http://w2.vatican. $\mathrm{va} /$ content/francesco/pt/messages/migration/documents/papa-francesco_20130805_ world-migrants-day.html. Acessado: 14.09.2014.

FREITAS JR., Antonio Rodrigues de. O trabalho à procura de um direito: crise econômica, conflitos de classe e proteção social na Modernidade. Estudos avançados, São Paulo, v. 28, n.81, pp. 69-93, 2014.

FREITAS, Vladimir Passos de (Org.). Comentários ao estatuto do estrangeiro e opção de nacionalidade. Campinas: Millennium, 2006.

GAMA, Luiz Carlos Day; MACHADO, Ana Flávia. Migração e rendimentos no Brasil: análise dos fatores associados no período intercensitário 2000-2010. Estudos Avançados, Belo Horizonte, v.28, n.81, 2014. pp. 155-174

HANTTON, T. J.; WILLIAMSON, J. G. Global Migration and the World Economy - Two centuries of policy and performance.Massachussetts: Instituteof Technology, 2005.

INSTITUTO BRASILEIRO DE GEOGRAFIA E ESTATÍSTICA - IBGE. Censo de 2010. Disponível em: http://censo2010.ibge.gov.br/. Acessado em: 10.09. 2014.

INSTITUTO DE MIGRAÇÕES E DIREITOS HUMANOS - IMDH. Migrantes: Quem são? Disponível em: http://www.migrante.org.br/migrante/index.php?option=com_content\&view=article\&id=219\&Itemid=1214. Acessado em: 10 .08.2014. 
JUBILUT, Liliana Lyra. O direito internacional dos refugiados e sua aplicação no ordenamento jurídico brasileiro. São Paulo: Método, 2007.

MEYERS, Eytan. InternationalImmigrationPolicy: A theoreticalandcomparativeanalysis. New York: PalgraveMacmillan, 2004.

MORIKAWA, Márcia Mieko. Deslocados internos: entre a soberania do estado e a proteção internacional dos direitos do homem: uma crítica ao sistema internacional de proteção dos refugiados. Coimbra: Editora Coimbra, 2006.

OLIVEIRA, Lucia Lippi. O Brasil dos imigrantes. Rio de Janeiro: Zahar, ISBN 97885-378-0303-5, 2001. e-book.

ORGANIZAÇÃO DAS NAÇÕES UNIDAS - ONU. Ata da $67^{a}$ Assembleia Geral das Nações Unidas (2012). Disponível em: http:/www.iom.int/cms/en/sites/ iom/home/about-migration/un-documents-1/67th-session-2012.html. Acessado em: 25.05.2014.

ORGANIZAÇÃO DAS NAÇÕES UNIDAS - ONU. Ata da $68^{a}$ Assembleia Geral das Nações Unidas, de julho de 2013. Disponível em: http://www.iom.int/cms/en/ sites/iom/home/about-migration/un-documents-1/68th-session-2012.html. Acessado em: 25.05.2014.

ORGANIZAÇÃO DAS NAÇÕES UNIDAS - ONU. Convenção da Organização das Nações Unidas de 1951 - Estatuto do Refugiado. Disponível em: http://www. pucsp.br/IIIseminariocatedrasvm/documentos/convencao_de_1951_relativa_ao_estatuto_dos_refugiados.pdf.Acessado em: 09.08.2014.

ORGANIZAÇÃO DAS NAÇÕES UNIDAS - ONU. Declaração Universal dos Direitos Humanosde 1948. Disponível em: http://portal.mj.gov.br/sedh/ct/legis_intern/ ddh_bib_inter_universal.htm. Acessado em: 14.09.2014.

ORGANIZAÇÃO INTERNACIONAL DO TRABALHO - OIT. Convenção $n$. 143, imigrações efectuadas em condições abusivas e sobre a promoção da igualdade de oportunidades e de tratamento dos trabalhadores migrantes.Disponível em: http://www.oitbrasil.org.br/content/conven $\% \mathrm{C} 3 \% \mathrm{~A} 7 \% \mathrm{C} 3 \% \mathrm{~A} 30$-sobre-imigra $\%$ C3\%A7\%C3\%B5es-efectuadas-em-condi\%C3\%A7\%C3\%B5es-abusivas-e-sobre-promo\%C3\%A7\%C3\%A3o-da-igualdade-de. Acessado em: 09.08.2014.

ORGANIZAÇÃO INTERNACIONAL DO TRABALHO - OIT. Convenção n. 97, trabalhadores migrantes, 22 jan. 1952. Disponível em: http://www.oitbrasil.org.br/ node/523. Acessado em: 09.08.2014.

ORGANIZAÇÃO INTERNACIONAL PARA MIGRAÇÃO - OIM. Migrantes qualificados. Disponível em: http:/www.brasil.iom.int/2013-01-24-22-48-46. Acessado em: 05.07.2014.

ORGANIZAÇÃO INTERNACIONAL PARA AS MIGRAÇÕES - OIM. Colóquio 
sobre direitos humanos na política migratória brasileira, set. 2013. Disponível em: http:/www.brasil.iom.int/2013-01-24-22-49-19. Acessado em: 15.10.2014.

INTERNATIONAL ORGANIZATION FOR MIGRATION - IOM. Labour migration and human development division: annual review, 2012. Disponível em: http://www.iom.int/files/live/sites/iom/files/What-We-Do/docs/LHD-Annual-Review-2012.pdf. Acessado em: 15.10.2014.

ORGANIZAÇÃO INTERNACIONAL PARA MIGRAÇÃO - OIM. Perfil migratório do Brasil 2009. (set. 2010) Disponível em: http://portal.mte.gov.br/data/files/ FF8080812CB90335012CBD3E35CB6605/perfil_migratorio_2009.pdf. Acessado em: 07.08.2014.

ORGANIZAÇÃO PARA A COOPERAÇÃO E DESENVOLVIMENTO ECONÔMICO - OCDE. Internationalmigration policies and data. Disponível em: http:// www.oecd.org/els/mig/imo2013.htm. Acessado em: 14.09.2014.

PARRATO, Neide et al. Políticas públicas e migração internacional no Brasil. São Paulo: Centro de Estudos Migratórios (CEM), 2011.

PROGRAMA DAS NAÇÕES UNIDAS PARA O DESENVOLVIMENTO - PNUD. Disponível em: http://hdr.undp.org/en/reports/research/. Acessado em: 12.05.2014.

REIS, Rossana Rocha. A política do Brasil para as migrações internacionais. Contexto internacional, São Paulo, n.1, v. 33, p. 47-69, 2011. Disponível em: http://www. scielo.br/scielo.php?pid=S0102-85292011000100003\&script=sci_arttext. Acessado em: 10.09.2014.

RIBEIRO, Graziele Cristina Lopes. Imigração globalizada e direito. 2013. 136 p. Dissertação (Mestrado em Direito) - Programa de Pós-Graduação Stricto Sensu em Direito, Universidade Católica de Brasília, Brasília, 2013.

RIZEK, Cibele Saliba; GEORGES, Isabel; SILVA, Carlos Freire. Trabalho e imigração: uma comparação Brasil-Argentina. Lua Nova, São Paulo, n. 79, p. 111-142, 2010. Disponível em: http://www.scielo.br/pdf/ln/n79/a06n79.pdf. Acessado em: 10.08.2014.

RODRIGUES, Viviane Mozine. Migrantes haitianos no Brasil: Mitos e Contradições.Disponível em: http://actacientifica.servicioit.cl/biblioteca/gt/GT9/GT9_MozineRodriguezV.pdf. Acessado em: 10.08.2014.

SICILIANO, André Luiz. A política migratória brasileira: limites e desafios. 2013. Dissertação (Mestrado em Direito) - Programa de Pós-Graduação Stricto Sensu em Direito, Universidade de São Paulo, São Paulo, 2013.

SPOLLE, Marcus Vinicius; FABRES, Ana Cristina Porto. Migração de trabalhadores especializados da construção naval: a experiência da construção de plataformas petroleiras do polo naval de Rio Grande. Disponível em: http://actacientifica.ser- 
vicioit.cl/biblioteca/gt/GT9/GT9_ViniciusMPortoA.pdf. Acessado em: 10.08.2014.

SUL-COREANOS formam o maior grupo de imigrantes no Ceará. Globo notícias (G1), 30 maio 2013. Disponível em: http://g1.globo.com/jornal-hoje/noticia/2013/05/sul-coreanos-formam-o-maior-grupo-de-imigrantes-no-ceara.html. Acessado em: 06.07.2014.

TEIXEIRA, Paula de Araújo Pinto. Direitos humanos dos refugiados. Prismas: Dir., Pol. Pub. e Mundial, Brasília, v. 6, n. 1, p. 15-34, jan./jun. 2009.

TOMÁZ, Marcela. Fluxos migracionais entre Brasil e Bolívia: imigração irregular, causas, vítimas e políticas migratórias. Disponível em: http://www.publicacoesacademicas.uniceub.br/index.php/relacoesinternacionais/article/ view/1121. Acessado em: 18.10.2014.

VENTURA, Deyse; ILLES, Paulo. Qual a política migratória do Brasil, 07 mar. 2012. Le monde diplomatique Brasil. Disponível em: http://www.diplomatique.org. br/artigo.php?id=1121. Acessado em: 11.08.2014.

ZOLBERG, A. R. A nation by design - Immigration Policy in the Fashioning of America.New York: Russell Sage Foundation, 2006.

ZOLO, Danilo. Globalizzazione: una mappa dei problemi. Roma-Bari: Laterza, 2004. 